\title{
Solonker ophiolite in Inner Mongolia, China: A late Permian continental margin-type ophiolite
}

\author{
Zhi-wen Luo ${ }^{a}$, Bei Xu ${ }^{\mathrm{a} * *}$, Guan-zhong Shi ${ }^{\mathrm{b}}$, Pan Zhao ${ }^{\mathrm{a}}$, M. Faure ${ }^{\mathrm{c}}$ and \\ Yan Chen ${ }^{\mathrm{c}}$
}

a. The Key Laboratory of Orogenic Belts and Crustal Evolution, Ministry of Education, School of Earth and Space Sciences, Peking University, Beijing, 100871, China

b. Key Laboratory of Tectonics and Petroleum Resources, Ministry of Education, China University of Geosciences, Wuhan 430074, China

c. Institute des Sciences de la Terre d'Orléans, UMR 7327 Université d'Orléans-INSU/CNRS, 1A rue de la Férollerie, 45071 Orléans, Cedex 2, France

\section{ABSTRACT}

The Solonker ophiolite is exposed along the border between Mongolia and China within the Solonker zone, the southeastern Central Asian Orogenic Belt (CAOB), and it is composed dominantly of serpentinized peridotite with subordinate gabbro, basaltic lava, radiolarian-bearing siliceous rocks, and minor plagiogranite. Meanwhile, layered mafic-ultramafic cumulates are not ubiquitous. In this study, zircon grains from two gabbros and a plagiogranite yield ${ }^{206} \mathrm{~Pb} /{ }^{238} \mathrm{U}$ ages of $259 \pm 6 \mathrm{Ma}, 257 \pm 3 \mathrm{Ma}$ and 263 $\pm 1 \mathrm{Ma}$. These data were interpreted to represent the formation age of the Solonker ophiolite. The studied gabbros and basalts have a tholeiitic composition, showing a MORB affinity. They are also characterized by enrichment of $\mathrm{Pb}$ and depletion of $\mathrm{Nb}$ relative to La and Th. Furthermore, the studied gabbros contain inherited zircon grains and display a large range of zircon $\mathrm{Hf}$ isotopes $(\varepsilon \mathrm{Hf}(\mathrm{t})=-5.27$ to +10.19$)$. These *Corresponding author. Tel.:010-62767288; fax: 010-62767288.

E-mail address: bxu@pku.edu.cn (B.Xu). 
features imply that crustal contamination played an important role in the generation of these mafic rocks. Major elements derived from the radiolarian-bearing siliceous rocks suggest a continental margin setting. This is confirmed by rock association. Terrigenous rocks (sandstones and siltstones) interstratified with siliceous rocks. U-Pb dating of detrital zircon grains in sandstones from both the northern and southern sides of the Solonker ophiolite belt, along with published data, reveals that the Late Carboniferous-Early Permian strata in fault contact with the Solonker ophiolite was deposited above Early Paleozoic orogens. The lines of petrological, geochemical, geochronological, and isotopic evidence led us to propose that the Solonker ophiolite is a Late Permian continental margin-type body formed during the early stages of opening of an ocean basin, following rifting and break-up of the Early Paleozoic orogens. Accordingly, the Permian Solonker zone is characterized by an intra-continental extensional setting.

\section{Introduction}

Ophiolites represent fragments of the upper mantle and oceanic crust (Coleman, 1977; Nicolas, 1989), and as such preserve records of the evolution and destruction of ancient oceanic lithosphere (Dilek, 2006; Dilek and Furnes, 2011; Furnes et al., 2015). They can provide key evidence to understand the evolution of both accretionary and collisional orogenic belts (Dilek, 2006; Furnes et al., 2015; Miao et al., 2008). Furthermore, ophiolites preserve varied structural architectures, chemical fingerprints, and related evolutionary paths, indicating different tectonic origins (Dilek, 2003). According to a recent study (Dilek and Furnes, 2011, 2014), ophiolites can be divided 
into subduction-unrelated and subduction-related categories. The subduction-unrelated ophiolites can further be subdivided into continental margin (CM)-type, mid-ocean ridge (MOR)-type, and plume (P)-type ophiolites. In particular, the CM-type ophiolites correspond to the Ligurian-type ophiolite, which were formed in the early stages of an ocean basin following the initiation of continental breakup. The subduction-related ophiolites include supra-subduction zone (SSZ)-type and volcanic arc (VA)-type. These five types of ophiolite are thus indicative of different tectonic settings and can be identified through their internal structures, geochemical signatures, and regional tectonics (Dilek and Furnes, 2011; Furnes et al., 2015).

The Central Asian Orogenic Belt (CAOB) is a giant accretionary orogen between the Siberian Craton (SC) to the north and the Tarim and North China Cratons (NCC) to the south (Fig. 1a; Şengör et al., 1993; Badarch et al., 2002; Jahn et al., 2004; Windley et al., 2007; Xiao et al., 2009). It was mainly formed by the subduction of the Paleo-Asian Ocean (PAO) and the subsequent amalgamation of terranes of different types and derivation (Coleman, 1994; Heubeck, 2001; Badarch et al., 2002; Xiao et al., 2003).

The PAO between the SC and NCC was first introduced by Zonenshain et al. (1990). Tectonic evolution of the PAO has long been a subject of extensive studies (Tang and Yan, 1993; Xiao et al., 2003, 2009; Miao et al., 2008; Jian et al., 2008, 2010; Zhang et al., 2011; Xu et al., 2013; Zhao et al., 2013), but the controversy concerning the timing and the exact location of its final closure has lasted over several decades. Some proposed that the PAO had closed by the end of the Devonian (Zhang and Tang, 
1989; Tang, 1990; Zhao et al., 2013). Recently, Xu et al. (2013) improved this model and further proposed that there was an independent micro-continental block within the PAO, i.e., the Hunshandake block, which approaches the northern margin of the NCC. The PAO was thus separated into the southern and northern branches. The southern branch closed during the Late Silurian, whereas the northern branch closed during the Late Devonian, resulting in the formation of the Southern and Northern orogenic belts, respectively (Xu et al., 2013). Following these orogenic events, the southeastern part of the CAOB underwent widespread continental rifting during the Late Paleozoic (Zhang and Tang, 1989; Tang, 1990; Chu et al., 2013; Shao et al., 2014), characterized by Early Permian alkaline A-type granitoids (Shi et al., 2004; Jahn et al., 2009), bimodal volcanic rocks (Zhang and Li, 1997; Zhu et al., 2001; Zhang et al., 2008), and extensional sedimentary basins (Tang 1990; Luo et al., 2015).

However, Jian et al. (2008) suggested that both the Southern and Northern orogenic belts were produced by the collision of continents and island arcs during the Late Silurian when the PAO still existed between these two orogenic belts. During the Early Permian, the PAO subducted beneath the NCC resulting in continental arc and ridge-trench collision, followed by the final closure of the PAO during the Late Permian-Early Triassic (Jian et al., 2008, 2010). Nevertheless, Xiao et al. (2003, 2009) argued that the double subduction of the PAO crust beneath the southern margin of the SC and the northern margin of the NCC lasted for the entire Paleozoic until collision occurred between the two opposing active continental margins. This led to the formation of the Solonker suture during the Late Permian (Xiao et al., 2003). Based on 
SHRIMP zircon $\mathrm{U}-\mathrm{Pb}$ ages and the geochemical features of the Late Paleozoic ultramafic-mafic rocks and granitic intrusions, Zhang et al. $(2007,2009)$ and Miao et al. (2008) also suggested that the final closure of the PAO along the Solonker suture occurred in the late Permian.

The Solonker zone (SZ) between the Southern and Northern orogenic belts, extending from Solonker, via Mandula, to Linxi, is thus a key area of study needed to clarify the above-mentioned debates. Nevertheless, the evolution of the SZ is still poorly understood, which is largely attributed to the lack of detailed studies on the ophiolite suites within this zone. An ophiolite belt, named the Solonker ophiolite (BGMR, 1982; Jian et al., 2008), is well preserved along the border between Mongolia and China in the western part of the SZ. In this paper, we present new detailed field observations, geochemical, and zircon $\mathrm{U}-\mathrm{Pb}$ dating results for the dominant lithologies (e.g., basalt and gabbro) from the Solonker ophiolite. Based on these new data, we discuss the age, nature, and tectonic setting of the Solonker ophiolite and provide important clues to unravel the tectonic evolution of the SZ and the timing of the final closure of the PAO.

\section{Geologic setting}

\subsection{Geologic outline}

From north to south, five units can be identified in the southeastern CAOB: the Xing'an-Airgin block (XAB) (South Mongolian microcontinent on the Mongolia side), the Northern orogenic belt (NOB), the Songliao-Hunshandake block (SHB), the Southern orogenic belt (SOB), and the northern margin of the NCC (Xu et al., 2013, 
2014, 2015; Fig. 1b). The western extension of the SOB and the NOB converge in the SZ.

\subsubsection{Northern orogenic belt (NOB)}

The NOB includes four sub-units from north to south: an arc-pluton belt, mélange, foreland molasse basin, and fold belt, which represent a northern subduction-collision system formed during 500-380 Ma between the SHB and XAB blocks (Xu et al., 2013). The arc-pluton belt, extending from Xilinhot, via Bayanbaolidao, to the north of the Solonker area, is composed of cumulate gabbros, gabbro-diorites, quartz diorites, tonalites, and granites, representing a magmatic arc formed from 500-420 Ma (Jian et al., 2008; Xu et al., 2013, 2015). The mélange with a high pressure metamorphic age of $383 \mathrm{Ma}$ (Xu et al., 2001) occurs from Honger, Naomuhunni, to Airgin Sum, marking the suture line of the NOB (Xu et al., 2013). Upper Devonian molassic deposits unconformably overlie the mélange (Zhang et al., 2010). The fold belt, occurring to the south of the mélange and the molasse basin, represents the northward-subducted passive margin of the SHB during the Early Paleozoic.

\subsubsection{Southern orogenic belt (SOB)}

The SOB, extending from Ondor Sum, via Bater, to the south of the Solonker area, represents a southern subduction-collision system between the NCC and SHB blocks during 500-440 Ma and includes two sub-units from north to south: the Ondor Sum subduction-accretion complex and an island arc belt (Jian et al., 2008; Xu et al., 2013). The Ondor Sum subduction-accretion complex consists of a subduction complex and an ophiolite, representing an Early Paleozoic accretionary wedge related to the 
southward subduction (Xiao et al., 2003; Jian et al., 2008). The island arc belt is made of volcanic rocks and plutons with an age of 425-488 Ma (Miao et al., 2007; Jian et al., 2008; Xu et al., 2013). Silurian flysch and the lower Devonian molasse deposits unconformably overly the island arc belt (Zhang et al., 2010; Xu et al., 2013).

\subsubsection{Songliao-Hunshandake block (SHB)}

The SHB occurs between the NOB and the SOB, and its western extension disappears in the SZ. The basement of the SHB is composed of Paleo- and Neo-Proterozoic granitic rocks, which has been well documented in the eastern part of the block (Xu et al., 2013, 2015). For example, a SHRIMP U-Pb zircon age of $1839 \pm$ $7 \mathrm{Ma}$ (Wang et al., 2006) for a granodiorite and an LA-ICPMS U-Pb zircon age of $1808 \pm 21$ Ma for a meta-gabbro (Pei et al., 2007) have been reported in the southeastern margin of this block. Late Paleozoic cover of this block is comprised of Carboniferous-Permian limestone, conglomerate, and sandstone (IMBGMR, 1991). The Carboniferous strata have been interpreted to be deposited in an inland sea after the Early Paleozoic orogenic events (Zhao et al., 2015), whereas a predominant shallow marine environment was proposed for the Permian strata (IMBGMR, 1991).

\subsection{Stratigraphy of the Solonker-Mandula area}

Carboniferous-Permian strata exposed in the Solonker-Mandula area along the Mongolia/China border are comprised of, from bottom to top, Late Carboniferous carbonate, Late Carboniferous-Early Permian carbonate/clastic rocks, Early Permian bimodal volcanic rocks and Hugierte-Chaganhadamiao volcanic-plutonic belt, Middle Permian carbonate/clastic rocks, and Late Permian turbidite (Figs. 2 and 3). 
The Late Carboniferous carbonates assigned as the Amushan Formation (Shi, 2013) were interpreted to be formed in an inland sea (Zhao et al., 2015), and consist of bioclastic limestone and sparite with fusulinids and crinoids. This succession has been thrusted onto the Late Carboniferous-Early Permian carbonate-clastic rocks caused by top-to-north thrusting (Fig. 3a). The Late Carboniferous-Early Permian carbonate-clastic rocks are mainly composed of interlayered fuchsia sandstone, siltstone, and limestone (Fig. 3b). They show features of normal sedimentary sequences with parallel bedding and are supposed to be marine-terrigenous deposits (IMBGMR, 1991). The repetitive sandstone and siltstone layers have a uniform southeastern dip.

The Early Permian bimodal volcanic rocks distributed in the northernmost part of the study area are mainly composed of rhyolitic and basaltic lavas. They are defined as the Dashizhai Formation with eruption ages of 280 Ma (Wang et al., 2005; Zhang et al., 2008). Tectonically sandwiched by the Late Carboniferous-Early Permian strata, the Hugierte-Chaganhadamiao volcanic-plutonic belt has eruption ages of 273-288 Ma (Jian et al., 2010; Chen et al., 2012), which is consistent with the age of the Dashizhai Formation. The volcanic rocks are mainly composed of pillow and massive basalt, dacite, and rhyolite with minor andesite (Fig. 3c). The plutonic rocks include gabbro, diorite, and plagiogranite.

The Middle Permian clastic-carbonate rocks assigned as the Zhesi Formation (Wang et al., 2005) are mainly composed of conglomerate and pebbly sandstone with subordinate fossil-bearing limestone (Fig. 3d). Overlying the Zhesi Formation, the Late 
Permian turbidite (Shi, 2013) is characterized by inter-layered mudstone, siltstone, and sandstone with variable thickness, similar to the Bouma sequence that commonly occurs in several outcrops (Fig. 3e). Olistostromes are developed at the bottom of the turbidite sequence. The presence of serpentinites (Fig. 3f) and siliceous rocks occurring as olistoliths in the matrix of sandstones and siltstones yields evidence for erosion of the Solonker ophiolite.

\section{Solonker ophiolite}

The E-W trending Solonker ophiolite is located in the western part of the SZ along the China/Mongolia border (Figs. 1b and 2). Based on our field observations, the Solonker ophiolite is dominated by peridotite, along with small volumes of gabbro, basalt, and siliceous rock with minor plagiogranite.

The extensively serpentinized peridotites are characterized by the development of tectonic breccias consisting of serpentinite cross-cut by calcite or dolomite veins at its top (Fig. 4a). The peridotite consists of serpentine, clinopyroxene, orthopyroxene, and some relict olivine (Fig. 5a), which suggests that the peridotite is lherzolite. The peridotites were intruded by gabbros in the western segment of the Solonker ophiolite on the Mongolian side (Jian et al., 2008).

In geologic section (I) of the mafic rocks in the Wuzhuershaobute area (Fig. 6a), the lower part mainly consists of a plutonic sequence with minor basalts. The plutonic sequence is composed of gabbros and rare diabases without sheeted dike complexes. In addition, gabbroic rocks are mainly composed of isotropic gabbros with rare cumulate gabbros (Fig. 4b). The gabbros mainly consist of clinopyroxene, plagioclase, and 
opaque minerals, exhibiting granular texture (Fig. 5b). They most likely experienced greenschist-faces metamorphism as exemplified by the presence of actinolite and chlorite.

The middle part of the section consists of interlayered basalts and siliceous rocks, whereas the upper part is mainly composed of basalts that were intruded by gabbros (Fig. 4d) and plagiogranite (Fig. 6a), and covered by siliceous rocks. The basalts occur as pillow lava and as massive flows (Fig. 4c). They are non-amygdaloidal and predominantly aphyric or slightly phyric and have also experienced greenschist-faces metamorphism as exemplified by the presence of actinolite and chlorite (Fig. 5c). The plagiogranite is medium-grained and hypidiomorphic and mainly consist of plagioclase and quartz (Fig. 5d).

In geologic section (II) of siliceous rocks near Bayanaobao (Fig. 6b), a few intercalations of sandstone and siltstone are observed (Figs. 4e-f). Radiolarians Pseudoalbaillella were also found in the siliceous rocks (Wang et al., 2005). Our field observations show that the siliceous rocks directly overlie the peridotite (Fig. 4g). As observed in thin sections, the siliceous rocks have a relatively high argillaceous component compared with typical pelagic siliceous rocks (Fig. 5e), indicating a proximal continental margin depositional setting.

On the southern side, the Late Carboniferous-Early Permian strata are in structural contact with the ophiolites through a high-angle south-dipping fault. The kinematic indicators along this fault show significant features of south to north thrusting (Fig. 4h). On the northern side, the ophiolite fragments are also in fault contact with the Late 
Carboniferous-Early Permian strata.

\section{Sample collection}

Four basalt, five gabbro, and five siliceous rock samples were collected for geochemical analyses (Fig. 6). Two gabbro samples (130808-08 and SGZ-3) were selected for $\mathrm{U}-\mathrm{Pb}$ zircon dating and $\mathrm{Hf}$ isotopic study (Fig. 2). A plagiogranite sample 141005-05 was also collected for U-Pb zircon dating (Fig. 6). A sandstone (140419-04) from the sedimentary sequence to the north of the ophiolite belt and a sandstone (141005-07) from the sedimentary sequence to the south of the ophiolite belt (Figs. 2 and 6) were collected for $\mathrm{U}-\mathrm{Pb}$ zircon dating to constrain the temporal relationship between the Solonker ophiolite and its surrounding strata.

Zircons were separated from the gabbro, plagiogranite and sandstone samples through standard heavy-liquid and magnetic techniques, and handpicked under a binocular microscope at the Chengxin Geology Service Co. Ltd, Langfang, Hebei Province, China. Cathodoluminescence (CL) imaging was performed using a FEI Quanta 200F scanning electron microscope at the Electron Microscopy Laboratory of Peking University to reveal the internal textures of zircons.

Zircon U-Pb dating for gabbro sample 130808-08 was conducted using the Cameca IMS-1280 SIMS at the Institute of Geology and Geophysics, Chinese Academy of Sciences. Detailed analytical procedures are described in Li et al. (2009). The O-primary ion beam with an intensity of ca. $10 \mathrm{nA}$ was accelerated at $-13 \mathrm{kV}$. The ellipsoidal spot is about $20 \mu \mathrm{m} \times 30 \mu \mathrm{m}$ in size. Calibration of $\mathrm{Pb} / \mathrm{U}$ ratios is relative to the standard zircon TEMORA2 (417 Ma) (Black et al., 2004) based on an observed 
linear relationship between $\ln \left({ }^{206} \mathrm{~Pb} /{ }^{238} \mathrm{U}\right.$ ) and $\ln \left({ }^{238} \mathrm{U}{ }^{16} \mathrm{O} /{ }^{238} \mathrm{U}\right.$ ) (Whitehouse et al., 1997). U and Th concentrations of unknowns are determined relative to the standard zircon 91500 with Th and $\mathrm{U}$ concentrations of ca. 29 and 81 ppm respectively (Wiedenbeck et al., 1995). Measured compositions were corrected for common $\mathrm{Pb}$ using ${ }^{204} \mathrm{~Pb}$. An average of present-day crustal composition (Stacey et al., 1975) is used for the common $\mathrm{Pb}$. Uncertainties on individual analyses are reported at $1 \sigma$ level; mean ages for pooled $\mathrm{U}-\mathrm{Pb}$ analyses are quoted with $95 \%$ confidence interval. Data reduction was carried out using the Isoplot/Ex v. 2.49 program.

Zircon U-Pb dating for gabbro sample SGZ-3, plagiogranite sample 141005-05 and sandstone samples were determined by Laser ablation-inductively coupled plasma-mass spectrometer (LA-ICP-MS) at the Key Laboratory of Orogen and Crust Evolution, Peking University. The instrument couples a quadrupole ICP-MS (Agilient 7500c) and 193-nm ArF Excimer laser (COMPexPro 102, Coherent, DE) with the automatic positioning system. Calibrations for the zircon analyses were carried out using NIST 610 glass as an external standard and Si as internal standard. U-Pb isotope fractionation effects were corrected using zircon Plesovice (337 Ma) as external standard. Zircon standard 91500 is also used as a secondary standard to supervise the deviation of age measurement/calculation. Isotopic ratios and element concentrations of zircons were calculated using GLITTER (verson 4.4.2, Macquarie University). Concordia ages and diagrams were obtained using Isoplot/Ex (3.0) (Ludwig, 2003). The common lead was corrected using LA-ICP-MS Common Lead Correction (verson 3.15), following the method of Andersen (2002). The analytical data are presented on 
$\mathrm{U}-\mathrm{Pb}$ Concordia diagrams with $1 \sigma$ errors. The mean ages are weighted means at $95 \%$ confidence levels (Ludwig, 2003).

In situ zircon Hf isotope analyses were conducted using a Neptune Plus MC-ICP-MS (Thermo Fisher Scientific, Germany) in combination with a Geolas 2005 excimer ArF laser ablation system (Lambda Physik, Göttingen, Germany) that was hosted at the state Key Laboratory of Geological Processes and Mineral Resources, China University of Geosciences in Wuhan. A "wire" signal smoothing device is included in this laser ablation system, by which smooth signals are produced even at very low laser repetition rates down to $1 \mathrm{~Hz}$ (Hu et al., 2012). The directly obtained $\beta_{\mathrm{Yb}}$ value from the zircon sample itself was applied in real-time in this study. The ${ }^{179} \mathrm{Hf} /{ }^{177} \mathrm{Hf}$ and ${ }^{173} \mathrm{Yb} /{ }^{171} \mathrm{Yb}$ ratios were used to calculate the mass bias of $\mathrm{Hf}\left(\beta_{\mathrm{Hf}}\right)$ and $\mathrm{Yb}\left(\beta_{\mathrm{Yb}}\right)$, which were normalized to ${ }^{179} \mathrm{Hf} /{ }^{177} \mathrm{Hf}=0.7325$ and ${ }^{173} \mathrm{Yb} /{ }^{171} \mathrm{Yb}=1.132685$ (Fisher et al., 2014) using an exponential correction for mass bias. Interference of ${ }^{176} \mathrm{Yb}$ on ${ }^{176} \mathrm{Hf}$ was corrected by measuring the interference-free ${ }^{173} \mathrm{Yb}$ isotope and using ${ }^{176} \mathrm{Yb} /{ }^{173} \mathrm{Yb}=0.79639$ (Fisher et al., 2014) to calculate ${ }^{176} \mathrm{Yb} /{ }^{177} \mathrm{Hf}$. Similarly, the relatively minor interference of ${ }^{176} \mathrm{Lu}$ on ${ }^{176} \mathrm{Hf}$ was corrected by measuring the intensity of the interference-free ${ }^{175} \mathrm{Lu}$ isotope and using the recommended ${ }^{176} \mathrm{Lu} /{ }^{175} \mathrm{Lu}$ $=0.02656$ (Blichert-Toft et al., 1997) to calculate ${ }^{176} \mathrm{Lu} /{ }^{177} \mathrm{Hf}$. We used the mass bias of $\mathrm{Yb}\left(\beta_{\mathrm{Yb}}\right)$ to calculate the mass fractionation of $\mathrm{Lu}$ because of their similar physicochemical properties. Off-line selection and integration of analytic signals, and mass bias calibrations were performed using ICPMSDataCal.

Major element analysis for siliceous rock samples was performed on an X-ray 
fluorescence spectrometer (XRF) at Key laboratory of Orogenic Belts and Crustal Evolution, Peking University, Ministry of Education, China. Analytical precision (relative standard deviation) is $<1 \%$ for the major elements. Major, trace and rare earth element analyses for basalt and gabbro samples were measured by ICP-emission spectrometry and inductively coupled plasma mass spectrometry (ICP-MS) at Acme Analytical Laboratories in Vancouver, Canada. Major elements were analyzed by the ICP-emission spectrometry method with detection limit $0.01 \%$. Loss on ignition (LOI) was determined by placing $1 \mathrm{~g}$ of samples in the furnace at $1000{ }^{\circ} \mathrm{C}$ for several hours before being cooled in a desiccator and reweighting. Trace and rare earth elements were analyzed by ICP-MS. The detection limit was around $0.1 \mathrm{ppm}$ for trace element, and around $0.01 \mathrm{ppm}$ for rare earth element. The analytical data are listed in Tables 5 and 6.

\section{Results}

\subsection{Zircon U-Pb dating}

\subsubsection{Gabbro and plagiogranite samples}

Zircons from gabbro sample 130808-08 exhibit a wide range of ages (Table 1; Figs. 7 and 8). The four youngest analyses cluster within the age range from $237 \pm 4$ Ma to $260 \pm 4 \mathrm{Ma}$. As the analysis with the age of $237 \pm 4 \mathrm{Ma}$ is discordant, possibly indicating later $\mathrm{Pb}$ loss or disturbance by a late tectonic-magmatic event. Thus, it is excluded from the calculations. The other three young analyses with ages ranging from 258 to 260 Ma yield a weighted mean age of $259 \pm 6$ Ma (Fig. 8b). These three zircons are subhedral to euhedral grains with oscillatory zoning, characteristic of magmatic 
crystallization (Fig. 7a and 7b). We thus consider the age of $259 \pm 6 \mathrm{Ma}$ to represent the time of igneous zircon crystallization. The ages of older zircons scatter from $282 \pm$ $4 \mathrm{Ma}$ to $1738 \pm 23 \mathrm{Ma}$. These zircons are well-rounded grains or fragments of larger grains (Fig. 7c and 7d) and are interpreted as inherited grains.

Zircons from gabbro sample SGZ-3 exhibit a similar age spectra to that of gabbro sample 130808-08 (Table 2; Fig. 8c). Five young zircons show oscillatory zoning or widely spaced growth zones, characteristic of mafic magmatic crystallization (Fig. 7e and 7f). They give a weighted mean age of $257 \pm 3 \mathrm{Ma}$ (Fig. 8d), which is interpreted to be the emplacement age of the gabbro. The remaining analyzed zircons with ages ranging from $\sim 278 \mathrm{Ma}$ to $\sim 1832 \mathrm{Ma}$ are interpreted as inherited grains (Fig. $7 \mathrm{~g}$ and $7 \mathrm{~h})$.

Most zircons from plagiogranite sample 141005-05 display typical oscillatory zoning (Fig. $7 \mathrm{i}$ and $7 \mathrm{j}$ ), indicating a magmatic origin. The youngest seven analyses show a relatively restricted range from $\sim 261$ to $\sim 265$ Ma and yield a mean ${ }^{206} \mathrm{~Pb} /{ }^{238} \mathrm{U}$ age of $263 \pm 1 \mathrm{Ma}$ (Fig. 8f), which is similar to the age of the gabbros within error and represents the age of igneous zircon crystallization. The older zircons with ages of 278-347 Ma (Fig. 8e) are interpreted as inherited grains (Fig. 7k and 71).

\subsubsection{Sandstone samples (140419-04 and 141005-07)}

The U-Pb ages of sandstone samples 140419-04 and 141005-07 are given in Table 4. As shown in Fig. 9, the two samples show the same detrital zircon U-Pb age distribution. The main group in sandstone sample 140419-04 yielded an age peak at 440 Ma (47 analyses) and a younger age peak at 280 Ma (22 analyses) (Fig. 9a). 
The remaining three old zircons yielded ages of $\sim 910 \mathrm{Ma}, \sim 1217 \mathrm{Ma}$, and $\sim 1801 \mathrm{Ma}$.

The zircons with ${ }^{206} \mathrm{~Pb} /{ }^{238} \mathrm{U}$ ages younger than $1000 \mathrm{Ma}$ in sandstone sample 141005-07 exhibit two evident peak ages at $440 \mathrm{Ma}$ (20 analyses) and $280 \mathrm{Ma}$ (31 analyses) with a few ages of 831 954 Ma (3 analyses). Zircons older than $1000 \mathrm{Ma}$ record ${ }^{207} \mathrm{~Pb} /{ }^{206} \mathrm{~Pb}$ ages of $1077 \mathrm{Ma}$ (1 analyses), $1503 \mathrm{Ma}$ (1 analysis), $1887 \mathrm{Ma}$ (1 analysis), 2168 Ma (1 analysis), and 2482-2540 Ma (5 analyses).

\subsection{Geochemistry}

\subsubsection{The gabbros and basalts}

The analyzed basalt and gabbro samples have $\mathrm{SiO}_{2}$ contents of 49.7-53.8 wt. \% and 44.4-47.9 wt. \%, respectively. All analyzed samples are mafic in composition in regard to silica, as shown by the TAS diagram (Fig. 10a). In the $\mathrm{FeO}^{\mathrm{T}} / \mathrm{MgO}$ vs $\mathrm{SiO}_{2}$ diagram (Fig. 10b), these mafic samples plot in the tholeiitic field with only one basalt sample plotting on the tholeiitic/calc-alkaline boundary. They have low $\mathrm{TiO}_{2}$ (0.13-0.63 wt. \%) and $\mathrm{P}_{2} \mathrm{O}_{5}\left(<0.01-0.06\right.$ wt. \%) contents but relatively high $\mathrm{Al}_{2} \mathrm{O}_{3}$ (14.03-19.34 wt. \%) and $\mathrm{CaO}(8.36-14.14$ wt. \%) contents. The $\mathrm{Mg}$ \# of the basalts and the gabbros ranges from 57 to 69 and from 67 to 77 , respectively.

The basalts have low $\Sigma$ REE, but they are higher than those of the gabbro samples. There is indeed a slight enrichment of LREE over HREE $\left(\mathrm{La}_{N} / \mathrm{Yb}_{\mathrm{N}}=0.84-2.28\right)$, but overall, the basalts display nearly flat REE patterns similar to that of N-MORB (Fig. 11a). The basalts have high $\mathrm{Y} / \mathrm{Nb}(6.0-17.6), \mathrm{Zr} / \mathrm{Nb}$ (11.7-53.6), and $\mathrm{La} / \mathrm{Nb}(>1)$, as is typically observed for N-MORB (Montanini et al., 2008). The N-MORB affinity of the basalts is also evident in the $\mathrm{Nb}^{*} 2-\mathrm{Zr} / 4-\mathrm{Y}$ diagram (Fig.13b) and the $\mathrm{TiO}_{2}-\mathrm{Nb} / \mathrm{Yb}$ 
diagram (Fig. 13c). In addition, the basalts exhibit low $\mathrm{Nb}$ and $\mathrm{Ta}$ and high $\mathrm{Sr}, \mathrm{Pb}$, and Ba, while they lack negative $\mathrm{Zr}$, Hf, and Ti anomalies (Fig. 12a), which are features of basalts contaminated with continental materials instead of typical subduction zone basalts (Xia, 2014).

The gabbros, however, generally have lower concentrations of $\mathrm{P}_{2} \mathrm{O}_{5}, \mathrm{Na}_{2} \mathrm{O}$, and incompatible elements than the basalts. Their REE patterns are characterized by slightly LREE-depletion $\left(\mathrm{La}_{N} / \mathrm{Yb}_{\mathrm{N}}=0.57-2.31\right)$ and nearly flat HREE like that of N-MORB (Fig.11a). The slightly positive Eu anomalies $\left(\mathrm{Eu} / \mathrm{Eu}^{*}=1.37-1.93\right)($ Fig. 11b) indicate the accumulation of plagioclase. Their average $\mathrm{Sm} / \mathrm{Nd}$ value $(0.38)$ is close to that of N-MORB (0.36; Sun and McDonough, 1989). In the primitive mantle (PM)-normalized spider diagram, however, the gabbros are characterized by enrichment of large ion lithophile elements (LILE) relative to high field strength elements (HFSE), which is different from typical N-MORB patterns (Fig. 12b). The Pb enrichment and $\mathrm{Nb}$ depletion relative to $\mathrm{La}$ and $\mathrm{Th}$ suggest involvement of continental crust or arc materials in the magma genesis (Miao et al., 2008), which may account for why the geochemical features of gabbros are not typical N-MORB. According to Pearce (2014), the involvement of trapped, relict continental lithosphere in an N-MORB magma can lead to distinctive, C (contaminated)-MORB compositions.

\subsubsection{The siliceous rocks}

As shown in Table 6, the siliceous rock samples from the study area consist dominantly of $\mathrm{SiO}_{2}$ and subordinately of $\mathrm{Al}_{2} \mathrm{O}_{3}$ and $\mathrm{Fe}_{2} \mathrm{O}_{3}{ }^{\mathrm{T}}$ (total $\mathrm{Fe}$ as $\mathrm{Fe}_{2} \mathrm{O}_{3}$ ). Contents of $\mathrm{SiO}_{2}$ range from 70.4 to 88.4 wt. \%, lower than those in classic pelagic 
siliceous rocks (Murray, 1994). Concentrations of $\mathrm{Al}_{2} \mathrm{O}_{3}$ and $\mathrm{Fe}_{2} \mathrm{O}_{3}{ }^{\mathrm{T}}$ vary from 4.03 to 15.7 wt. $\%$ and 2.84 to 6.43 wt. $\%$, respectively. Concentrations of the other constituents are generally lower than 2 wt. \%, except for those of $\mathrm{K}_{2} \mathrm{O}$ and $\mathrm{Na}_{2} \mathrm{O}$.

\subsubsection{Hf isotopes}

Lu-Hf isotopic data for 8 young zircon grains from the two gabbro samples are presented in Table 7. The ${ }^{176} \mathrm{Lu} /{ }^{177} \mathrm{Hf}$ and ${ }^{176} \mathrm{Yb} /{ }^{177} \mathrm{Hf}$ ratios range from 0.000574 to 0.005385 and from 0.013953 to 0.134999 , respectively. These 8 magmatic zircons with ages of $254-261 \mathrm{Ma}$ have $\varepsilon \mathrm{Hf}(\mathrm{t})$ values ranging from -5.27 to +10.19 , with the majority $>0$ (Fig. 13d), suggesting that the gabbro was dominantly mantle-derived and experienced crustal contamination during magmatic evolution (Griffin et al., 2002).

\section{Discussion}

\subsection{Formation age of the Solonker ophiolite}

Our new age data for two gabbros give consistent ages and yields weighted mean ages of $259 \pm 6 \mathrm{Ma}$ and $257 \pm 3 \mathrm{Ma}$. Zircon $\mathrm{U}-\mathrm{Pb}$ dating shows that the crystallization age of the plagiogranite sample is $263 \pm 1 \mathrm{Ma}$, similar to the ages of gabbros within analytical errors. In addition, a $248 \pm 2 \mathrm{Ma}$ gabbro has also been reported at the western segment of the Solonker ophiolite in Mongolia (Jian et al., 2008). Therefore, the Solonker ophiolite is interpreted to has formed from the late Middle-Permian to the late Late-Permian.

\subsection{Sedimentary setting of Late Carboniferous-Early Permian strata}

Sandstones from the Late Carboniferous-Early Permian strata on both sides of the Solonker ophiolite belt show similar age spectra (Fig. 9), indicating that they were 
deposited in the same basin. The repetitive layers of reddish sandstone, siltstone, and limestone suggest that this sedimentary sequence represents shallow marine or marine-terrigenous deposits.

The peak age of $\sim 440$ Ma matches the episode of arc magmatism recognized in the NOB and the SOB (Jian et al., 2008; Xu et al., 2013), while the peak age of 280 Ma overlaps with the age of volcanic rocks of the Dashizhai Formation (Zhang et al., 2008). Furthermore, the 431-477 Ma (Jian et al., 2008) and 438 Ma (Miao et al., 2007) arc magmatic recognized in the study area (Fig. 2) are interpreted to be the western extension of the NOB and the SOB, respectively (Xu et al., 2015). This indicates that the Late Carboniferous-Early Permian strata was developed above the Early Paleozoic orogens, consistent with a previous interpretation (Zhao et al., 2015). The zircon U-Pb ages of $\sim 1800 \mathrm{Ma}$ and $\sim 2500 \mathrm{Ma}$ correspond to the most important tectono-thermal events of the NCC (Zhao et al., 2001, 2005; Zhai et al., 2005; Peng et al., 2010; Piper et al., 2011). In addition, sandstones from the southern side have more zircon ages of $\sim 1800 \mathrm{Ma}$ and $\sim 2500 \mathrm{Ma}$ than sandstones from the northern side. Therefore, we propose that the Late Carboniferous-Early Permian strata was deposited in an inland sea developed above the Early Paleozoic orogens on the northern margin of the NCC.

\subsection{Type and tectonic setting of the Solonker ophiolite}

According to Dilek (2003) and Dilek and Furnes (2011, 2014), the CM-type ophiolites generally represent ocean-continent transitional crust formed during the early stages of an ocean basin, following initial breakup of a continent. These ophiolites are characterized by widespread serpentinized peridotites that are intruded 
by small to moderate volumes of gabbro. They do not include sheeted dike complexes, and the peridotites underlie both basaltic lava flows and oceanic sediments (Piccardo et al., 2001). The crustal rocks display normal (N)-MORB-like geochemical signatures. Locally, the involvement of trapped, relict, continental lithosphere can lead to distinctive, contaminated, (C)-MORB compositions (Pearce, 2014).

\subsubsection{Evidence for a CM-type body from petrological analyses}

The SZ has long been considered as the end-Permian suture between the SC and NCC. The ophiolite fragments, together with the Carboniferous-Permian strata, were previously designated as the classic Solonker ophiolitic mélange developed in this area (BGMR, 1982; Xiao et al., 2003; Tao et al., 2004; Jian et al., 2010). However, our field observations reveal that the Carboniferous-Permian strata show features of normal sedimentary sequences instead of mélange (Figs. 3b-3e). The ultramafic blocks and siliceous blocks, occurring as olistoliths in the matrix of sandstones and siltstones, should be olistostromes developed at the bottom of a turbidite (Fig. 3f); while the large limestone blocks occurring as olistoliths in the Late Carboniferous-Early Permian strata are derived from the Amushan Formation and their tectonic emplacement is associated with the top-to-north thrusting (Fig. 3a). Furthermore, the mafic rocks experienced only low-grade metamorphism, as described in Section 3. Therefore, we suggest that the Solonker ophiolite belt and the Carboniferous-Permian strata are not the ophiolitic mélange. Instead, we propose that the Solonker ophiolite in the SZ may represent some dismembered ophiolite fragments, which occur as tectonic slices within the Carboniferous-Permian strata. As discussed above, on the southern side, the Late 
Carboniferous-Early Permian strata are in contact with the Solonker ophiolite along high-angle south-dipping faults (Fig. 4h). Therefore, the tectonic emplacement of the Solonker ophiolite into its present location occurred due to south-dipping thrusting.

Petrologically, the Solonker ophiolite shows the following features: (a) serpentinized peridotites make up the bulk of ophiolites, while mafic rocks are only subordinate; (b) tectonic breccias, classified as ophicalcites (Boillot and Froitzheim, 2001), overlie the serpentinized peridotites; (c) the plutonic sequences are composed of gabbro and rare diabase without sheeted dike complexes; (d) siliceous rocks underlie the basalts (Fig. 5a); (e) significant volumes of layered mafic-ultramafic cumulates are not ubiquitous; (f) the gabbro intrudes the peridotite and basalt; and (g) the siliceous rocks directly overlie the peridotites. These are diagnostic characteristics of ophiolites formed during the early stages of the opening of an ocean basin (Boillot and Froitzheim, 2001; Desmurs et al., 2002; Dilek and Furnes, 2011, 2014). This type of ophiolite is classified as a CM-type (Dilek and Furnes, 2011, 2014) or Ligurian-type ophiolite (Dilek, 2003). Similar petrological characteristics were reported for the Ligurian and Western Alpine ophiolites (Bernoulli and Weissert, 1985; Piccardo et al., 2001; Desmurs et al., 2002; Rampone et al., 2005; Manatschal and Müntener, 2009; Dilek and Furnes, 2011) and the Jormua ophiolite in Northeastern Finland (Peltonen et al., 1996), which were interpreted to be formed in an embryonic ocean basin. In addition, the presence of sandstones and siltstones in the siliceous rock section (II) indicates that these oceanic siliceous rocks are associated with a terrigenous sedimentary system. Therefore, they may have been formed in a proximal continental 
margin setting rather than in a deep-sea setting. These petrological analyses, thus, support the idea that the Solonker ophiolite is a CM-type body formed during the early stages of the opening of an ocean basin.

\subsubsection{Evidence for a CM-type body from geochemistry of the mafic rocks}

As described above, the mafic rocks display tholeiitic and MORB affinities, characteristic of CM-type ophiolites (Dilek and Furnes, 2011, 2014). Similar geochemical features have also been reported for other CM-type ophiolites, such as the Ligurian and Western Alpine ophiolites (Piccardo et al., 2001; Montanini et al., 2008).

Basalts carry the best records of the tectonic setting of ophiolites (Zhang, 2014). In the Ti-Zr-Y diagram (Fig. 13a), most of the basalt samples plotted within the MORB field rather than the island arc field, implying a non-subduction environment for these basalts. Whereas the one sample that plots in the island arc field may be associated with contamination by continental crust or lithosphere, which can impart subduction-like signatures (Pearce, 2008; Zhang and Zhou, 2013; Xia, 2014). This is further evidenced by the $\mathrm{Pb}$ enrichment and $\mathrm{Nb}$ depletion relative to $\mathrm{La}$ and $\mathrm{Th}$ in these mafic rocks (Fig. 12b). Moreover, no Late Paleozoic high-pressure subduction complex has been found in the study area. Therefore, the Solonker ophiolite could have formed in a MOR-like rifting environment rather than a forearc setting (e.g., Jian et al., 2010), as is also suggested in Section 5.2.1. This result further supports the conclusion based on the petrological analyses that the Solonker ophiolite is a CM-type body formed during the early stages of the opening of an ocean basin.

\subsubsection{Evidence for a CM-type body from geochemistry of the siliceous rocks}


Siliceous rocks provide important information on the tectonic setting of ophiolites (Girty et al., 1996; Dilek, 2003). Murray (1994) proposed the use of volatile-free values of $\mathrm{Al}_{2} \mathrm{O}_{3}, \mathrm{TiO}_{2}$, and $\mathrm{Fe}_{2} \mathrm{O}_{3}$ to discriminate average near-ridge, pelagic (i.e., mid-oceanic), and continental margin sediments. On the $\mathrm{Fe}_{2} \mathrm{O}_{3} / \mathrm{TiO}_{2}$ vs. $\mathrm{Al}_{2} \mathrm{O}_{3} /\left(\mathrm{Al}_{2} \mathrm{O}_{3}+\mathrm{Fe}_{2} \mathrm{O}_{3}\right)$ and $\mathrm{Fe}_{2} \mathrm{O}_{3} /\left(100-\mathrm{SiO}_{2}\right)$ vs. $\mathrm{Al}_{2} \mathrm{O}_{3} /\left(100-\mathrm{SiO}_{2}\right)$ discrimination diagrams (Fig. 14), most siliceous rock samples plot within either (1) the continental margin field overlapping with the pelagic field, or (2) the continental margin field. These results suggest a continental margin depositional environment, consistent with our field observations that sandstones and siltstones are found interstratified with siliceous rocks. Similar results have been documented for siliceous rocks in the Ligurian and Western Alpine ophiolites (Manetti et al., 1979). Therefore, the geochemical analyses of the siliceous rocks again support the idea that the Solonker ophiolite is a CM-type body.

\subsubsection{Evidence for a CM-type body from zircon inheritance and Hf isotopic data}

\section{of the gabbros}

As discussed in Section 5.1, the zircon U-Pb data indicate the presence of inherited zircons in the gabbro and plagiogranite, with ages ranging from $~ 280 \mathrm{Ma}$ to 1832 Ma. Zircon inheritance is common in continental igneous rocks (Pideon and Compston, 1992), but has not been previously reported in ophiolites, which are formed in oceanic environments (Miao et al., 2008). Zircon inheritance may be a common feature of ophiolites formed in immature ocean basins (Miao et al., 2008; Li et al., 2015). Representative examples of this phenomenon are the cumulate gabbros from the 
Hegenshan ophiolite (Miao et al., 2008) and the plagiogranites from the Ligurian ophiolite (Borsi et al., 1996), which represent fragments of embryonic oceanic crust and contain zircons from the continental crust. Accordingly, the inherited zircons in the gabbro and plagiogranite indicate that the Solonker ophiolite may have been formed in an embryonic ocean basin. In addition, the inherited zircon ages can provide chronological information on the continental crust that was rifted to form the ocean basin. The youngest inherited zircon ages ( 280 Ma) of the Solonker ophiolite correspond to the youngest peak ages ( $280 \mathrm{Ma})$ of sandstones from the Late Carboniferous-Early Permian strata. Therefore, we propose that the ocean basin opened after the deposition of the Late Carboniferous-Early Permian strata.

Hf isotopic features of the gabbros suggest that crustal contamination occurred during the magmatic ascent, which further supports that the ocean basin opened between pieces of rifted continental basement.

To sum up, our new petrological, geochemical, geochronological, and Hf isotopic data indicate that the Solonker ophiolite is a CM-type body that formed in an extensional environment during the early stages of the opening of an ocean basin, following rifting and break-up of the Early Paleozoic orogens.

\subsection{The Hugierte-Chaganhadamiao volcanic-plutonic belt}

Tao et al. (2003) proposed that the volcanic-plutonic belt exposed in the Hugierte-Chaganhadamiao area is of island arc magmatism, resulting from the subduction of the PAO beneath the NCC during the Early Permian. Jian et al. (2010) suggested a forearc setting for the formation of this volcanic-plutonic belt and 
interpreted it as the fragments of the Solonker ophiolite formed during the Early Permian. Chen et al. (2012) considered this unit to be part of an ophiolite complex formed in an immature ocean basin during the Early Permian. These ideas are challenged by our new field observations, and the following discussion offers alternative interpretations.

As described in Section 2.2, the volcanic rocks of this unit are mainly composed of pillow and massive basalts, dacite, and rhyolite with minor andesite (Fig. 3c), which define a bimodal succession that is consistent with the geochemical data from Jian et al. (2010). Therefore, the volcanic rocks are the products of coeval mafic and felsic volcanism commonly formed in extensional environments (Frost et al., 1999; Zhang et al., 2008), which is consistent with the field observation that this unit is sandwiched by Late Carboniferous-Early Permian strata. Additionally, the presence of rhyolite suggests that this unit is unlikely to be part of an ophiolite (Zhang et al., 2014).

The bimodal volcanic rocks that are assigned to the Dashizhai Formation to the north have magmatic eruption ages of ca. 280 Ma (IMBGMR, 1991; Zhang et al., 2008), consistent with the formation age of the Hugierte-Chaganhadamiao volcanic-plutonic sequence. It is widely accepted that the Dashizhai Formation was formed in an extensional setting (Zhu et al., 2001; Zhang et al., 2008; Zeng et al., 2011). Therefore, we suggest that this volcanic-plutonic belt is likely a part of the Dashizhai Formation rather than a component of the Solonker ophiolite.

\section{Tectonic model}

Based on SHRIMP zircon U-Pb ages of the Late Paleozoic ultramafic-mafic rocks 
and granitoid intrusions as well as their geochemical signatures, the PAO has been considered to be closed by the latest Permian (Xiao et al., 2003; Zhang et al., 2007, 2009; Jian et al., 2008, 2010; Xiao et al., 2009). The new data in this paper suggests that these ultramafic-mafic rocks are a CM-type body formed in a newly opened ocean basin rather than the remnants of the PAO. The Late Carboniferous to Early Permian and Late Permian-Middle Triassic suite of granitoid intrusions on the northern margin of the NCC (Zhang et al., 2007, 2009) may be alkaline A-type granitoids formed in an extensional setting, such as that suggested by Shi et al. (2004) for the Early Permian granites exposed in the Xilinhot area. Therefore, we propose an intra-continental extension model to explain the evolution of the SZ during the Permian:

(1) During the Late Carboniferous-Early Permian, the Late Carboniferous-Early Permian strata were deposited in an inland sea developed on the Early Paleozoic orogens (Fig. 15A);

(2) In the Early Permian, extension of the Early Paleozoic orogens covered by the Late Carboniferous-Early Permian strata took place leading to the development of the bimodal magmatism of the Dashizhai Formation (Fig. 15B);

(3) In the Middle Permian, the Zhesi Formation developed in a weak continental extensional setting, which is supported by the observation that few coeval magmatic rocks are observed from the area (Fig. 15C);

(4) In the Late Permian, continued continental extension leads to the onset of sea-floor spreading and the development of turbidites. The Solonker ophiolite was formed during the early stages of this spreading, following rifting and break-up of the 
Early Paleozoic orogens (Fig. 15D); and

(5) After the Permian, the closure of this small ocean basin led to the tectonic emplacement of the Solonker ophiolite into its present location, which occurred due to North-directed thrusting (Fig. 15E).

\section{Conclusions}

(1) The dating of gabbros and plagiogranites suggests that the Solonker ophiolite formed from the late Middle-Permian to the late Late-Permian.

(2) The Solonker ophiolite is not the remnant of the Paleo-Asian Ocean. Instead, it is a continental margin-type body that formed during the early stages of opening of an ocean basin, following rifting and break-up of the Early Paleozoic orogens covered by Late Carboniferous-Early Permian strata.

(3) The tectonic evolution of the Solonker zone in the Permian is characterized by intra-continental extension.

\section{Acknowledgements}

We thank Wang Yanyang, Liao Wen, Zhang Chenhao and Yan Linjie for their help in field trips, Su Li and Ma Fang for their help in ICP-MS analyses of zircons. We gratefully acknowledge constructive reviews from three anonymous reviewers. This work has been funded by the National Key Basic Research Program of China (2013CB429806), and the National Science Foundation of China (40872145 and 41121062). 


\section{References}

Andersen, T., 2002. Correction of common lead in $\mathrm{U}-\mathrm{Pb}$ analyses that do not report ${ }^{204} \mathrm{~Pb}$. Chemical Geology 192, 59-79.

Badarch, G., Cunningham, W.D., Windley, B.F., 2002. A new terrane subdivision for Mongolia: implications for the Phanerozoic crustal growth of Central Asia. Journal of Asian Earth Sciences 21, 87-104.

Blichert-Toft, J., Albaradel, F., 1997. The Lu-Hf isotope geochemistry of chondrites and the evolution of the mantle-crust system. Earth and Planetary Science Letters 148, 243-56.

Black, L.P., Kamo, S.L., Allen, C.M., Donald, W.D., Aleinikoff, J.N., Valley, J.W., Mundil, R., Campbell, I.H., Korsch, R.J., Williams, I.S., Foudoulis, C., 2004. Improved ${ }^{206} \mathrm{~Pb} /{ }^{238} \mathrm{U}$ micro-probe geochronology by the monitoring of a trace-element-related matrix effect; SHRIMP, ID-TIMS, ELA-ICP-MS and oxygen iso-tope documentation for a series of zircon standards. Chemical Geology 205, 115-140.

Boillot, G., Froitzheim, N., 2001. Non-volcanic rifted margins, continental break-up and the onset of sea-floor spreading: some outstanding questions. Geological Society, London, Special Publications 187, 9-30.

Borsi, L., Scharer, U., Gaggero, L., Crispini, L., 1996. Age, origin and geodynamic significance of plagiogranite in Iherzolites and gabbros of the Piedmont-Ligurian ocean basin. Earth and Planetary Science Letters 140, 227-241.

Bernoulli, B., Weissert, H., 1985. Sedimentary fabrics in Alpine ophicalcites, South 
Pennine Arosa zone, Switzerland. Geology 13, 755-758.

BGMR (Bureau of Geology and Mineral Resources of Nei Mongol Autonomous Region), 1982. Regional Geology of Nei Mongol (Inner Mongolia) Autonomous Region. Geological Publishing House, Bejing., 1-725.

Chen, C., Zhang, Z.C., Guo, Z.J., Li, J.F., Feng, Z.S., Tang, W.H., 2012. Geochronology, geochemistry, and its geological significance of the Permian Mandula mafic rocks in Damaoqi, Inner Mongolia. Science China (Earth Sciences) $55,39-52$.

Chen, Y., Zhang, Z.C., Li, K., Li, Q.G., Luo, Z.W., 2015. Provenance of the Middle Permian Zhesi Formation in central Inner Mongolia, Northern China: constraints from petrography, geochemistry and detrital zircon $\mathrm{U}-\mathrm{Pb}$ geochronology. Geological Journal, DOI: 10.1002/gj.2735.

Chu, H., Zhang, J.R., Wei, C.J., Wang, H.C., Ren, Y.W., 2013. A new interpretation of the tectonic setting and age of meta-basic volcanics in the Ondor Sum Group, Inner Mongolia. Chinese Science Bulletin 58(28/29), 3580-3587.

Coleman, R.G., 1977. Ophiolites: New York, Springer-Verlag, Berlin-Heidelberg-New York, (220 pp).

Coleman, R. G., 1994. Reconstruction of the Paleo-Asian Ocean. VSP Int. Sci. Publ., Utrecht, Netherlands.

Desmurs, L., Müntener, O., Manatschal, G., 2002. Onset of magmatic accretion within a magma-poor rifted margin: a case study from the Platta ocean-continent transition, eastern Switzerland. Contributions to Mineralogy and Petrology 144, 
$365-382$.

Dilek, Y., .2003. Ophiolite concept and its evolution. Geological Society of America Special Papers 371, 1-16.

Dilek, Y., 2006. Collision tectonics of the Eastern Mediterranean region: causes and consequences. Geological Society of America Special Paper 409, 1-13.

Dilek, Y., Furnes, H., 2011. Ophiolite genesis and global tectonics: geochemical and tectonic fingerprinting of ancient oceanic lithosphere. Geological Society of America Bulletin 123 (3/4), 387-411.

Dilek, Y., Furnes, H., 2014. Ophiolites and their origins. Elements 10, 93-100.

Fisher, C. M., Vervoort, J.D., Hanchar, J.M., 2014. Guidelines for reporting zircon Hf isotopic data by LA-MC-ICPMS and potential pitfalls in the interpretation of these data. Chemical Geology 363, 125-133.

Frost, C.D., Frost, B.R., Chamberlain, K.R., Edwards, B.R., 1999. Petrogenesis of the 1.43 Ga Sherman batholith, SE Wyoming, USA: a reduced, rapakivitype anorogenic granite. Journal of Petrology 40, 1771-1802.

Furnes, H., Dilek, Y., Wit, M.D., 2015. Precambrian greenstone sequences represent different ophiolite types. Gondwana Research 27, 649-685.

Gerdes, A., Zeh, A., 2006. Combined U-Pb and Hf isotope LA-(MC-)ICP-MS analyses of detrital zircons: comparison with SHRIMP and new constraints for the provenance and age of an Armorican metasediment in Central Germany. Earth and Planetary Science Letters 249, 47-61.

Girty, G.H., Ridge, D.L., Knaack, C., Johnson, D., Al-Riyami, K.A., 1996. Provenance 
and deposition setting of Paleozoic chert and argillite, Sierra Nevada, California. Journal of Sedimentary Research 66, 107-118.

Griffin, W.L., Wang, X., Jackson, S.E., Pearson, N.J., O’Reilly, S.Y., Xu, X.S., Zhou, X.M., 2002. Zircon chemistry and magma mixing, SE China: In-situ analysis of Hf isotopes, Tonglu and Pingtan igneous complexes. Lithos 61, 237-269.

Heubeck, C., 2001. Assembly of central Asia during the middle and late Paleozoic, in Paleozoic and Mesozoic Tectonic Evolution of Central and Eastern Asia, edited by M. S. Hendrix and G. A. Davis, Geological Society of America Memoir 194, $1-22$.

Heumann, M.J., Johnson, C.L., Webb, L.E., Taylor, J.P., Jalbaa, U., Minjin, C., 2012. Paleogeographic reconstruction of a late Paleozoic arc collision zone, southern Mongolia. Geological Society of America Bulletin 124, 1514-1534.

Hu, Z.C., Liu, Y.S., Gao, S., Xiao, S.Q., Zhao, L.S., Günther, D., Li, M., Zhang, W., Zong, K.Q., 2012. A “wire” signal smoothing device for laser ablation inductively coupled plasma mass spectrometry analysis. Spectrochimica Acta Part B 78, $50-57$.

IMBGMR (Inner Mongolian Bureau of Geology and Mineral Resources), 1991. Regional Geology of Inner Mongolian Autonomous Region. Geological Publishing House, Beijing. 726 pp (in Chinese with English abstract).

Jahn, B.M., Windley, B., Natal'in, B., Dobretsov, N., 2004. Phanerozoic continental growth in Central Asia. Journal of Asian Earth Sciences 23, 599-603.

Jahn, B.M., Litvinovsky, B.A., Zanvilevich, A.N., Reichow, M., 2009. Peralkaline 
granitoid magmatism in the Mongolian-Transbaikalian Belt: Evolution, petrogenesis and tectonic significance. Lithos 113, 521-539.

Jian, P., Liu, D., Kröner, A., Windley, B.F., Shi, Y., Zhanf, F., Shi, G., Miao, L., Zhang, W., Zhang, Q., Zhang, L., Ren, J., 2008. Time scale of an early to mid-Paleozoic orogenic cycle of the long-lived Central Asian Orogenic Belt, Inner Mongolia of China: implications for continental growth. Lithos 101, 233-259.

Jian, P., Liu, D.Y., Kröner, A., Windley, B.F., Shi, Y.R., Zhang, W., Zhang, F.Q., Miao, L.C., Zhang, L.Q., Tomurhuu, D., 2010. Evolution of a Permian intraoceanic arc-trench system in the Solonker suture zone, Central Asian Orogenic Belt, China and Mongolia. Lithos 118(1-2), 169-190.

Le Maitre, R.W., Bateman, P., Dudek, A., Keller, J., Lameyre, J., Le Bas, M.J., Sabine, P.A., Schmid, R., Sorensen, H., Streckeisen, A., Woolley, A.R., Zanettin, B., 1989. A Classification of Igneous Rocks and Glossary of Terms. Blackwell, Oxford.

Lagabrielle, Y., Lemoine, M., 1997. Alpine, Corsican and Apennine ophiolites: the slow-spreading ridge model. Earth and Planetary Sciences 325, 909-920.

Li, X.H., Liu, Y., Li, Q.L., Guo, C.H., Chamberlain, K.R., 2009. Precise determination of Phanerozoic zircon $\mathrm{Pb} / \mathrm{Pb}$ age by multicollector SIMS without external standardization, Geochemistry Geophysics Geosystems 10, 1-21.

Li, X.H., Faure, M., Rossi, P., Lin, W., Lahondère, D., 2015. Age of Alpine Corsica ophiolites revisited: Insights from in situ zircon $\mathrm{U}-\mathrm{Pb}$ age and $\mathrm{O}-\mathrm{Hf}$ isotopes. 
Lithos 220-223, 179-190.

Ludwig, K.R., 2003. User's Manual for Isoplot 3.0: A Geochronological Toolkit forMicrosoft Excel Berkeley Geochronology Center. Special Publication 4 pp. $1-71$

Luo, Z.W., Zhang, Z.C., Li, K., Li, J.F., Tang, W.H., Xu, B., 2016. Petrography, geochemistry, and $\mathrm{U}-\mathrm{Pb}$ detrital zircon dating of Early Permian sedimentary rocks from the North Flank of the North China Craton: Implications for the Late Paleozoic tectonic evolution of the eastern Central Asian Orogenic Belt. International Geology Review 58, 787-806.

Manatschal, G., Müntener, O., 2009. A type sequence across an ancient magma-poor ocean-continent transition: The example of the western Alpine Tethys ophiolites. Tectonophysics 473, 4-19.

Manetti, P., Peccerillo, A., Poli, G., 1979. Rare earth element distribution in Jurassic siliceous rocks from Northern Apennines (Italy). Mineralogica et Petrographica Acta 23, 87-98.

Meschede, M., 1986. A method of discriminating between different types of midocean ridge basalts and continental tholeiites with the $\mathrm{Nb}-\mathrm{Zr}-\mathrm{Y}$ diagram. Chemical Geology 56, 207-218.

Miao, L., Zhang, F., Fan, W.M., Liu. D., 2007. Phanerozoic evolution of the Inner Mongolia-Daxinganling orogenic belt in North China: constraints from geochronology of ophiolites and associated formations, Geological Society, London, Special Publications 280, 223-237.

Miao, L.C., Fan, W.M., Liu, D.Y., Zhang, F.Q., Shi, Y.R., Guo, F., 2008. 
Geochronology and geochemistry of the Hegenshan ophiolitic complex: Implications for late-stage tectonic evolution of the Inner Mongolia-Daxinganling Orogenic Belt, China. Journal of Asian Earth Sciences 32, 348-370.

Miyashiro, A., 1974. Volcanic rock series in island arcs and active continental margins. American Journal of Science 274, 321-355.

Montanini, A., Tribuzio, R., Vernia, L.G., 2008. Petrogenesis of basalts and gabbros from an ancient continent-ocean transition (External Liguride ophiolites, Northern Italy). Lithos 101, 453-479.

Murray, R.W., 1994. Chemical criteria to identify the depositional environment of chert:general principles and applications. Sedimentary Geology 90, 213-232.

Nicolas, A., 1989. Structure of Ophiolites and Dynamics of Oceanic Lithosphere: Dordrecht, the Netherlands, Kluwer Academic Publishers, pp. 367.

Pearce, J.A., Cann, J.R., 1973. Tectonic setting of basic volcanic rocks determined using trace element analyses. Earth and Planetary Science Letters 19, 290-300.

Pearce, J.A., 2008. Geochemical fingerprinting of oceanic basalts with applications to ophiolite classification and the search for Archean oceanic crust. Lithos 100, $14-48$.

Pearce, J.A., 2014. Immobile element fingerprinting of ophiolites. Elements 10, 101-108.

Pei, F.P., Xu, W.L., Yang, D.B., Zhao, Q.G., Liu, X.M., Hu, Z.C., 2007. Zircon U-Pb geochronology of basement metamorphic rocks in the Songliao Basin. Chinese Science Bulletin 52 (7), 942-948. 
Peltonen, P., Kontinen A., Huhma.H., 1996. Petrology and Geochemistry of Metabasalts from the 1.95 Ga Jormua Ophiolite, Northeastern Finland. Journal of Petrology 37(6), 1359-1383.

Peng, P., Guo, J.H., Zhai, M.G., Bleeker, W., 2010. Paleoproterozoic gabbronoritic and granitic magmatism in the northern margin of the North China Craton: evidence of crust-mantle interaction. Precambrian Research 183, 635-659.

Piccardo, G.B., Rampone, E., Romairone, A., Scambelluri, M., Tribuzi, R., Eretta, C.B., 2001. Evolution of the Ligurian Tethys: inference from petrology and geochemistry of the Ligurian Ophiolites. Periodico di Mineralogia 70(2), 147-192.

Pideon, R.T., Compston, W., 1992. A SHRIMP ion microprobe study of inherited and magmatic zircons from four Scottish Caledonian granites. Transactions of the Royal Society of Edinburgh: Earth Sciences 83, 473-483.

Piper, J.D.A., Zhang, J.S., Huang, B., Roberts, A.P., 2011. Palaeomagnetism of Precambrian dyke swarms in the North China Shield: the $\sim 1.8$ Ga LIP event and crustal consolidation in late Palaeoproterozoic times. Journal of Asian Earth Sciences 41, 504-524.

Rampone, E., Romairone, A., Abouchami, W., Piccardo, G.B., Hofmann, A.W., 2005. Chronology, petrology, and isotope geochemistry of the Erro-Tobbio peridotites (Ligurian Alps, Italy): Records of late Palaeo zoic lithospheric extension. Journal of Petrology 46, 799-827.

Şengör, A.M.C., Natal'in, B.A., Burtman, V.S., 1993. Evolution of the Altaid tectonic 
collage and Paleozoic crustal growth in Eurasia. Nature 364, 299-307.

Shao, J.A., Tang, K.D., He, G.Q., 2014. Early Permian tectono-palaeogeographic reconstruction of Inner Mongolia, China. Acta Petrologica Sinica 30, 1858-1866 (in Chinese with English abstract).

Shi, G.Z., 2013. The Central Asian Orogen Belt Paleozoic tectonic evolution in Central Inner Mongolia, China. Doctoral thesis, Peking University, Beijing.

Shi, G.H., Miao, L.C., Zhang, F.Q., Jian, P., Fan, W.M., Liu, D.Y., 2004. The age and its regional tectonic implication of the Xilinhot A-type granites, Inner Mongolia. Chinese Science Bulletin 49, 384-389.

Stacey, J.S., Kramers, J.D., 1975. Approximation of terrestrial lead isotope evolution by a two-stage model. Earth and Planetary Science Letters 26, 207-221.

Sun, S.S., McDonough, W.F., 1989. Chemical and isotopic systematic of oceanic basalts:implications for mantle composition and processes. In: Saunders, A.D., Norry, M.J.(Eds.), Magmatism in Ocean Basins: Geological Society (London) Special Publication 42, pp. 313-345.

Tang, K.D., 1990. Tectonic development of Paleozoic foldbelts at the North margin of the Sino-Korean Craton. Tectonics 9, 249-260.

Tang, K., Yan, Z., 1993. Regional metamorphism and tectonic evolution of the Inner Mongolian suture zone. Journal of Metamorphic Geology 11, 511-522.

Tao, J.X., Bai, L.B., Bao, J.W.LJ., Zheng, W.J., Su, R.M., 2003. Rock record of Permian subducting orogenic process in Mandula, Inner Mongolia. Geological Survey and Research 26, 241-249 (in Chinese with English abstract). 
Tao, J.X., Su, M.R, Bao,Y., Wu, L.J., Bai, L.B., 2004. Characteristics and tectonic significance of the Solon Mountain ophiolitic melange in the Mandula area, Darhan Muminggan, Inner Mongolia. Geological Bulletin of China 23(12), 1238-1242 (in Chinese with English abstract).

Wang, H., Wang, Y.J., Chen, Z.Y., LI, Y.X., Su, M.R., Bai, L.B., 2005. Discovery of the Permian radiolarians from the Bayanaobao area, Inner Mongolia. Journal of Stratigraphy 29(4), 368-371 (in Chinese with English abstract).

Wang, Y., Zhang, F.Q., Zhang, D.W., Miao, L.C., Li, T.S., Xie, H.Q., Meng, Q.R., Liu, D.Y., 2006. Zircon SHRIMP U-Pb dating of meta-diorite from the basement of the Songliao Basin and its geological significance. Chinese Science Bulletin 51 (15), 1877-1883.

Windley, B.F., Alexeiev, D., Xiao, W.J., Kroner, A., Badarch, G., 2007. Tectonic models for accretion of the Central Asian Orogenic belt. Journal of the Geological Society, London 164, 31-47.

Whitehouse, M.J., Claesson, S., Sunde, T., Vestin, J., 1997. Ion-microprobe U-Pb zir-con geochronology and correlation of Archaean gneisses from the Lewisian Complex of Gruinard Bay, north-west Scotland. Geochimica et Cosmochimica Acta 61, 4429-4438.

Wiedenbeck, M., Alle, P., Corfu F, Griffin, W.L., Meier, M., Oberli, F., Vonquadt, A., Roddick, J.C., Spiegel, W., 1995. Three natural zircon standards for U-Th-Pb, Lu-Hf, trace-element and REE analyses. Geostandards Newsletter 19, 1-23.

Xia, L.Q., 2014. The geochemical criteria to distinguish continental basalts from arc 
related ones. Earth-Science Reviews 139, 195-212.

Xiao, W.J., Windley, B.F., Hao, J., Zhai, M.G., 2003. Accretion leading to collision and the Permian Solonker suture, Inner Mongolia, China: Termination of the central Asian orogenic belt. Tectonics 22 (6), 1-18.

Xiao, W.J., Windley, B.F., Huang, B.C., Han, C.M., Yuan, C., Chen, H.L., Sun, M., Sun, S., Li, J.L., 2009. End-Permian to mid-Triassic termination of the accretionary processes of the southern Altaids: implications for the geodynamic evolution, Phanerozoic continental growth, and metallogeny of Central Asia. International Journal of Earth Sciences 98, 1189-1217.

Xu, B., Charvet, J., Zhang, F.Q., 2001. Primary study on petrology and geochronology of the blueschist in Sonid Zuoqi, northern Inner Mongolia. Chinese Journal of Geology 36, 424-434 (in Chinese with English abstract).

Xu, B., Charvet, J., Chen, Y., Zhao, P., Shi, G.Z., 2013. Middle Paleozoic convergent orogenic belts in western Inner Mongolia (China): framework, kinematics, geochronology and implications for tectonic evolution of the Central Asian Orogenic Belt. Gondwana Research 23(4), 1342-1364.

Xu, B., Zhao, P., Bao, Q.Z., Zhou, Y.H., Wang, Y.Y., Luo, Z.W., 2014. The pre-Mesozoic tectonic unit division of the Xing-Meng orogenic belt (XMOB). Acta Petrologica Sinica 30 (7), 1841-1857 (in Chinese with English abstract).

Xu, B., Zhao, P., Wang, Y.W., Liao, W., Luo, Z.W., Bao, Q.Z., Zhou, Y.S., 2015.The pre-Devonian tectonic framework of Xing'an-Mongolia orogenic belt (XMOB) in north China. Journal of Asian Earth Sciences 97, 183-196. 
Zeng, W.S., Zhou, J.B., Zhang, X.Z., Qiu, H.J., 2011. LA-ICP-MS zircon U-Pb age of the volcanic rocks from the Dashizhai Formation in Keyouqianqi, Inner Mongolia, China and its tectonic setting. Geological Bulletin of China 30(2/3), 270-277 (in Chinese with English abstract).

Zhang, Y.P., Tang, K.D., 1989. Pre-Jurassic tectonic evolution of intercontinental region and the suture between the North China and Siberian platforms. Journal of Southeast Asian Earth Science 3, 47-55.

Zhang, Q., 2014. Classifications of mafic-ultramafic rocks and the their tectonic significance. Chinese Journal of Geology 49(3), 982-1017 (in Chinese with English abstract).

Zhang, C., Li, M.S., 1997. The features of Late Paleozoic tectono-manmatic activity and crustal revolution in the southern suzuoqi area. Geological Journal of China Universities 3, 31-39 (in Chinese with English abstract).

Zhang, S.H., Zhao, Y., Song, B., Yang, Z.Y., Hu, J.M., Wu, H., 2007. Carboniferous granitic plutons from the northern margin of the North China block: implications for a late Palaeozoic active continental margin. Journal of the Geological Society of London 164, 451-463.

Zhang, S.H., Zhao, Y., Song, B., Hu, J.M., Liu, S.W., Yang, Y.H., Chen, F., Liu, X.M., Liu, J., 2009. Contrasting Late Carboniferous and Late Permian-Middle Triassic intrusive suites from the northern margin of the North China Craton: Geochronology petrogenesis, and tectonic implications. Geological Society of America Bulletin 1-2, 181-200. 
Zhang, X.H., Zhang, H. F., Tang, Y.J., Wilde, S.A., Hu, Z.C., 2008. Geochemistry of Permian bimodal volcanic rocks from Central InnerMongolia, North China: Implication for tectonic setting and Phanerozoic continental growth in Central Asian Orogenic Belt. Chemical Geology 249, 261-281.

Zhang, X.H., Wilde, S.A., Zhang, H. F., Zhai, M.G., 2011. Early Permian high-K calc-alkaline volcanic rocks from NW Inner Mongolia,North China: geochemistry, origin and tectonic implications. Journal of the Geological Society, London 168, $525-543$

Zhang, Y.P., Su, Y.Z., Li, J.C., 2010. Regional tectonics significance of the Late Silurian Xibiehe Formation in central Inner Mongolia, China. Geological Bulletin of China 29 (11), 1599-1605 (in Chinese with English abstract).

Zhang, C.L., Zou, H.B., 2013. Comparison between the Permian mafic dykes in Tarimand the western part of Central Asian Orogenic Belt (CAOB), NW China: implications for two mantle domains of the Permian TarimLarge Igneous Province. Lithos 174, 15-27.

Zhai, M.G., Guo, J.H., Liu, W.J., 2005. Neoarchean to Paleoproterozoic continental evolution and tectonic history of the North China Craton: a review. Journal of Asian Earth Sciences 24, 547-561.

Zhao, G.C., Wilde, S.A., Cawood, P.A., Sun, M., 2001. Archean blocks and their boundaries in the North China Craton: Lithological, geochemical, structural and P-T path constraints and tectonic evolution. Precambrian Research 107, 45-73.

Zhao, G.C., Sun, M., Wilde, S.A., Li, S.Z., 2005. Late Archean to Paleoproterozoic evolution of the North China Craton: key issues revisited. Precambrian Research 
136, 177-20.

Zhao, P., Chen, Y., Xu, B., Faure, M., Shi, G.Z., Choulet, F., 2013. Did the Paleo-Asian Ocean between North China Block and Mongolia Block exist during the late Paleozoic? First paleomagnetic evidence from central-eastern Inner Mongolia, China. Journal of Geophysical Resarch: Solid Earth 118, 1873-1894.

Zhao, P., Xu, B., Tong, Q.L., Chen, Y., Faure, M., 2015. Sedimentological and geochronological constraints on the Carboniferous evolution of central InnerMongolia, southeastern Central Asian Orogenic Belt: Inland sea deposition in a post-orogenic setting. Gondwana Research, In press.

Zhu, Y.F., Sun, S.H., Gu, L.B., Ogasawara, Y., Jiang, N., Honma, H., 2001. Permian volcanism in the Mongolian orgenic zone, northeast China: geochemistry, magma sources and petrogenesis. Geological Magazine 138, 101-115.

Zonenshain, L.P., Kuzmin, M.I., Natapov, L.M., 1990. Geology of the USSR, A Plate Tectonic Synthesis, American Geophysical Union, Geodynamics Series 21.Washington, DC pp. 1-242. 


\section{Figure Captions}

Fig. 1. (a) The location of the XMOB in central and East Asia (after Şengör et al., 1993). (b) Geological sketch map of the XMOB showing the distribution of late Paleozoic strata and the main tectonic units (Jian et al., 2008; Heumann et al., 2012; Chen et al., 2015; Xu et al., 2015).

Fig. 2. Simplified geological map of the study area (after Wang et al., 2005; Jian et al., 2010). The dashed line marks the China/Mongolia border. Lines I and II show the locations of the sections displayed in Figure 6.

Fig. 3. Simplified stratigraphic section and field photos of Late Carboniferous-Permian strata in the study area. a. Limestones of the Late Carboniferous Amushan Formation occur as nappes above the Late Carboniferous-Early Permian strata. b. Red coarse-grained sandstones of the Late Carboniferous-Early Permian strata. c. Bimodal distribution of volcanic rocks among the Early Permian volcanic-plutonic sequence. d. Repetitive layers of pebbly sandstones and limestones in the Middle Permian Zhesi Formation. e. Bouma sequences in the Late Permian turbidite. f. Olistostromes showing ultramafic blocks in the matrix of sandstones and siltstones at the bottom of the turbidite.

Fig. 4. Field photos of the different members of the Solonker ophiolite. See text for details.

Fig. 5. Photomicrographs of the different members of the Solonker ophiolite.

Fig. 6. Geological section of the Solonker ophiolite showing the sample locations. a. Geological section of the mafic rocks occurring in the Wuzhuershaobute area. b. 
Geological section of the siliceous rocks exposed near Bayanaobao.

Fig. 7. Representative CL images of zircons from gabbro sample 130808-08 (a-d), gabbro sample SGZ-3 (e-h), and plagiogranite sample 141005-05 (i-l).

Fig. 8. Concordia plot of $\mathrm{U}-\mathrm{Pb}$ zircon analytical results for gabbros and plagiogranites from the Solonker ophiolite.

Fig. 9. Relative age probability diagram for sample 140419-04 and sample 141005-07, which were collected from the north side and the south side of the Solonker ophiolite belt, respectively.

Fig. 10. (a) Silica vs. total Alkalis (TAS) diagram (Le Maitre et al., 1989) of basalt and gabbro samples. (b) Plot of $\mathrm{SiO}_{2}$ versus FeOT/MgO (after Miyashiro, 1974) for basalt and gabbro samples. Symbols in Fig. 11 and Fig. 13 are the same as those in this figure.

Fig. 11. Chondrite normalized REE patterns for the (a) gabbros and (b) basalts of the Solonker ophiolite (E-MORB, OIB compositions and N-MORB normalization values are from Sun and McDonough, 1989).

Fig. 12. Primitive mantle-normalized spider diagrams for the (a) gabbros and (b) basalts of the Solonker ophiolite (normalization values are from Sun and McDonough, 1989).

Fig. 13. Plots of (a) Ti/100-Zr-Y*3 (after Pearce and Cann, 1973), (b) Nb*2-Zr/4-Y (after Meschede, 1986), (c) $\mathrm{TiO}_{2}-\mathrm{Nb} / \mathrm{Yb}$ (after Pearce 2014), and (d) $\varepsilon \mathrm{Hf}_{\mathrm{t}}$ versus crystallization ages of zircons from the gabbros in the study area (Gerdes and Zeh, 2006). $\mathrm{MORB}=$ Mid Ocean Ridge Basalts; OIB = oceanic island basalt; $\mathrm{N}-\mathrm{MORB}=$ 
Normal Mid-Ocean Ridge Basalts; P-MORB = Plume-influenced Mid-Ocean Ridge Basalts; and E-MORB = Enriched Mid-Ocean Ridge Basalts.

Fig. 14. a. $\mathrm{Fe}_{2} \mathrm{O}_{3} /\left(100-\mathrm{SiO}_{2}\right)$ vs $\mathrm{Al}_{2} \mathrm{O}_{3} /\left(100-\mathrm{SiO}_{2}\right)$ discrimination diagram from Murray (1994). b. $\mathrm{Fe}_{2} \mathrm{O}_{3} / \mathrm{TiO}_{2}$ vs $\mathrm{Al}_{2} \mathrm{O}_{3} /\left(\mathrm{Al}_{2} \mathrm{O}_{3}+\mathrm{Fe}_{2} \mathrm{O}_{3}\right)$ from Murry (1994).

Fig. 15. Generalized evolutionary model for the Solonker zone during the Permian (modified after Lagabrielle and Lemoine, 1997; Piccardo et al., 2001; Dilek and Furnes, 2011). SZ: Solonker zone; NCC: North China craton; SOB: Southern orogenic belt; and NOB: Northern orogenic belt. 


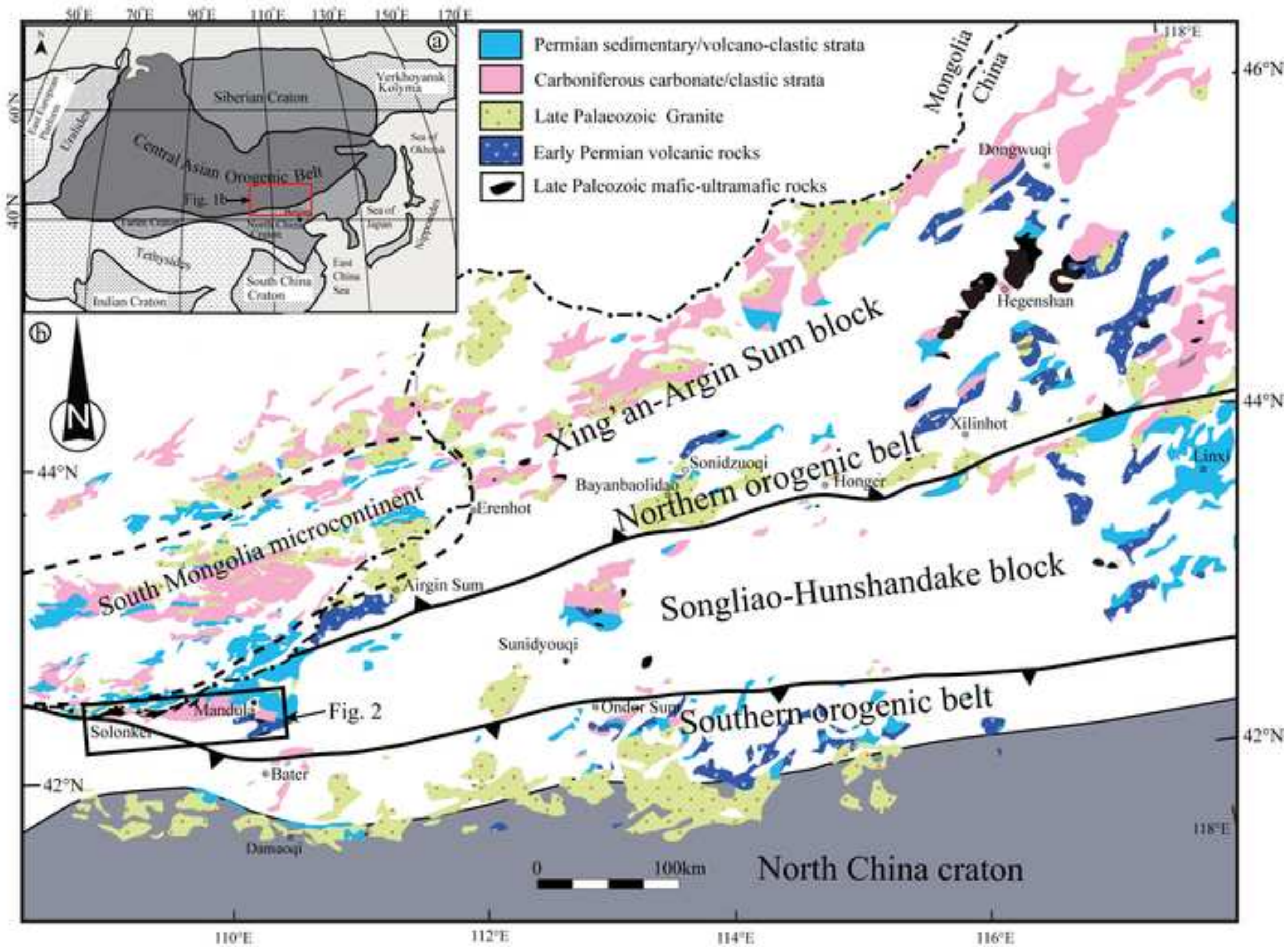




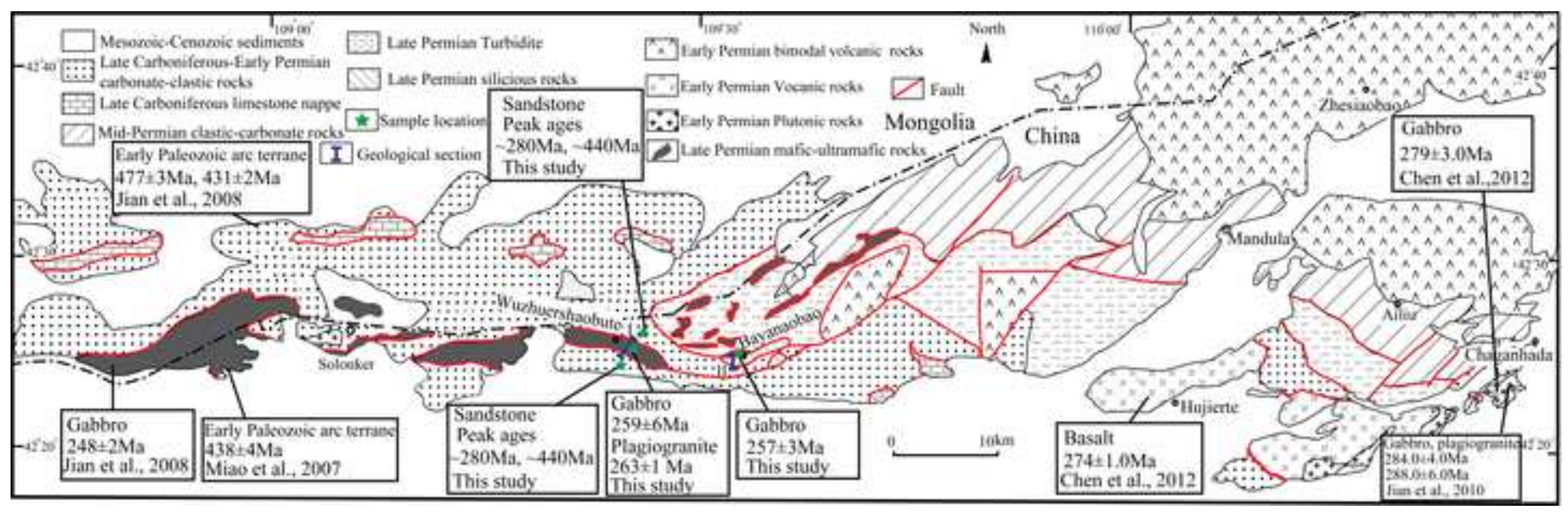




\begin{tabular}{|c|c|}
\hline$\frac{\text { E }}{\text { E }}$ & $\begin{array}{l}\text { Solonker } \\
\text { ophiolite }\end{array}$ \\
\hline $\begin{array}{l}\frac{\mathrm{E}}{\mathrm{n}} \\
\frac{\mathrm{E}}{\mathrm{E}} \\
\frac{\mathrm{e}}{\mathrm{E}} \\
\frac{\mathrm{g}}{2}\end{array}$ & $\begin{array}{l}\text { Zhesi } \\
\text { Formation: } \\
\text { Clastic- } \\
\text { carbonate rocks }\end{array}$ \\
\hline 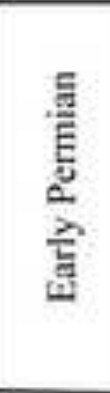 & $\begin{array}{l}\text { Dashizhai } \\
\text { Formation: } \\
\text { Bimodal } \\
\text { succession/ }\end{array}$ \\
\hline 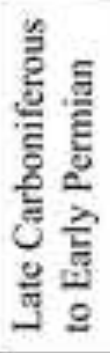 & $\begin{array}{l}\text { Carbonate- } \\
\text { clastic rocks }\end{array}$ \\
\hline 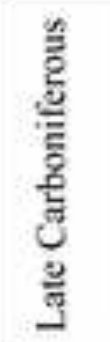 & $\begin{array}{l}\text { Amushan } \\
\text { Formation: } \\
\text { Limestone }\end{array}$ \\
\hline
\end{tabular}

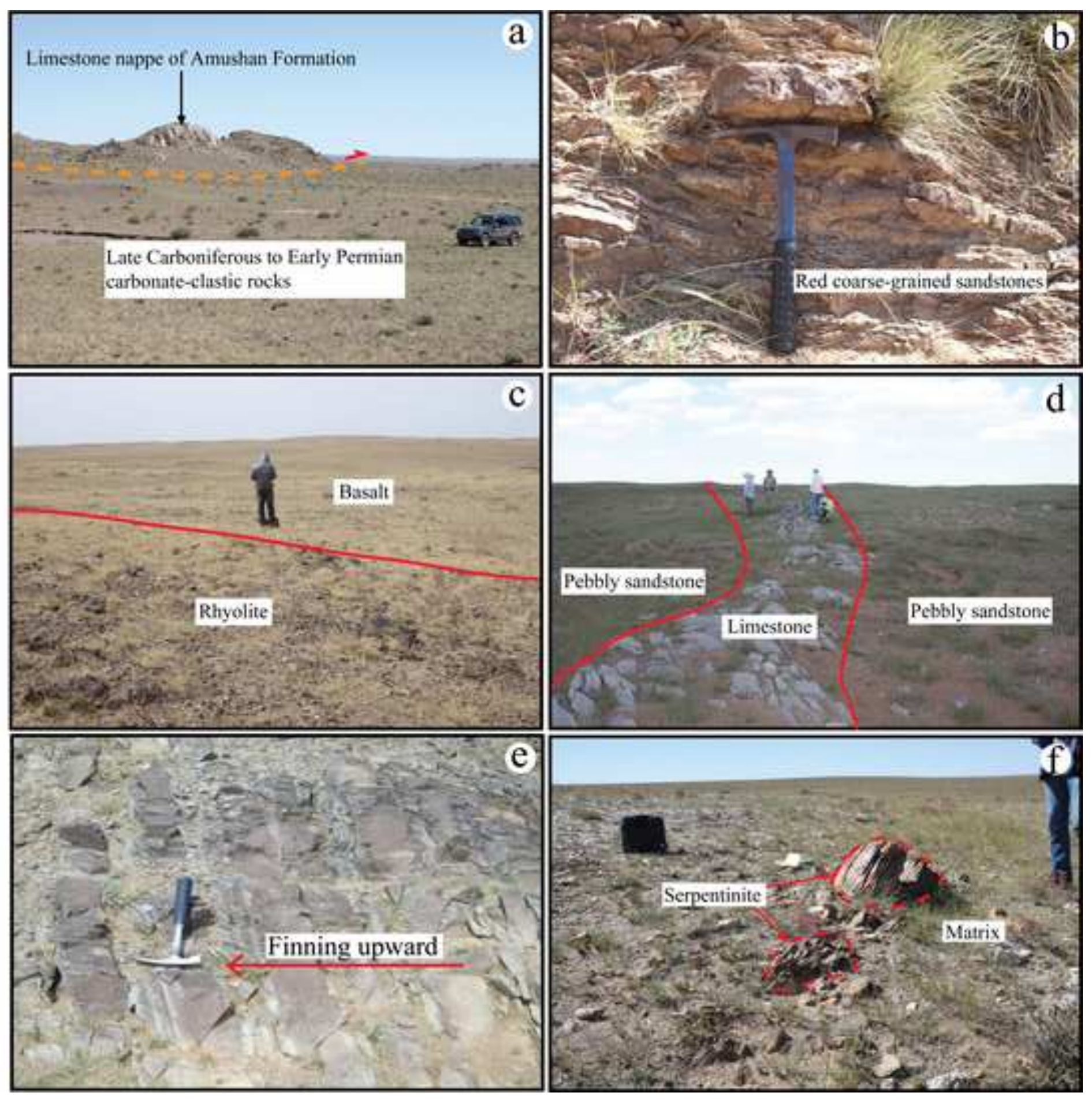



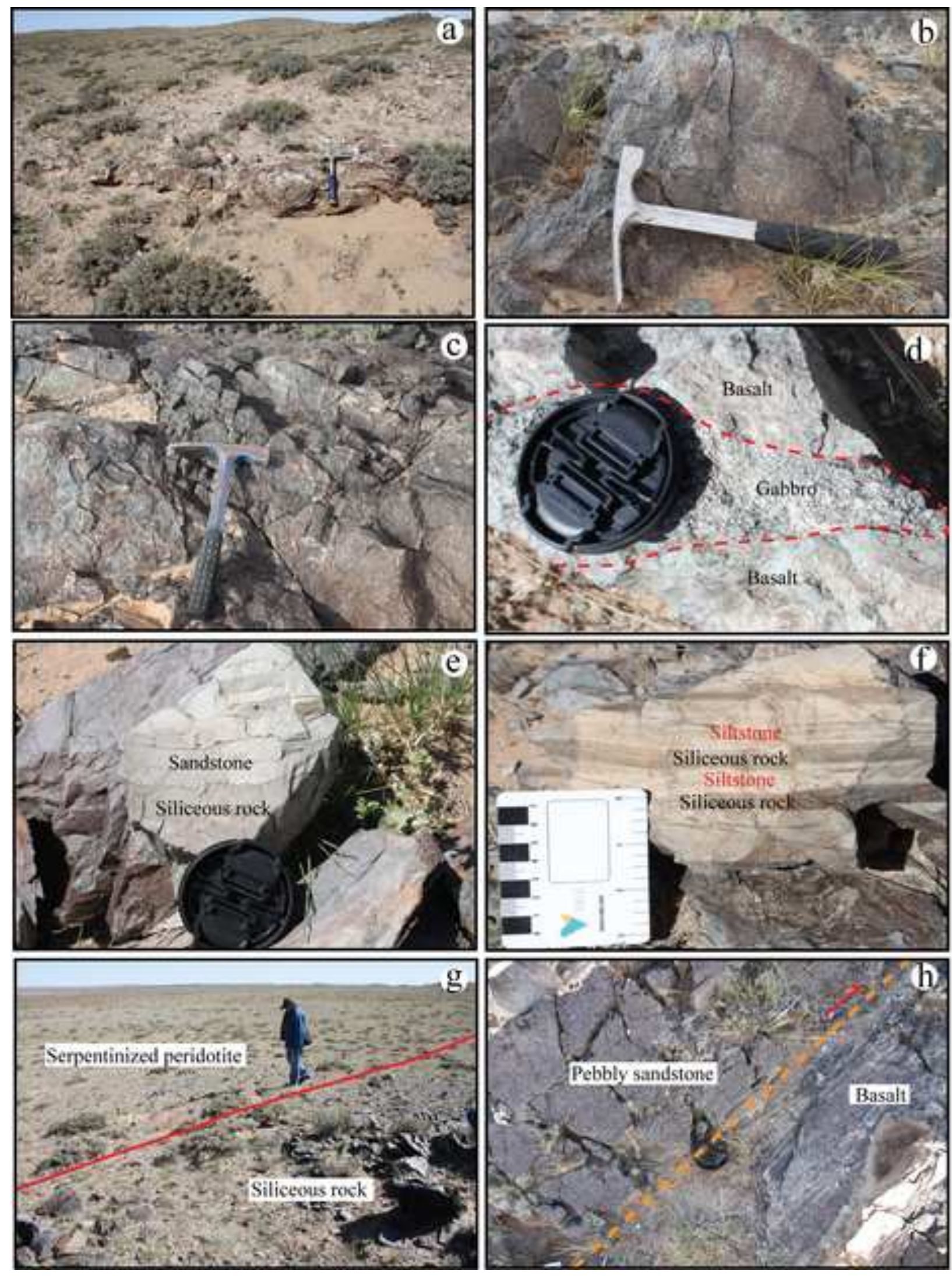

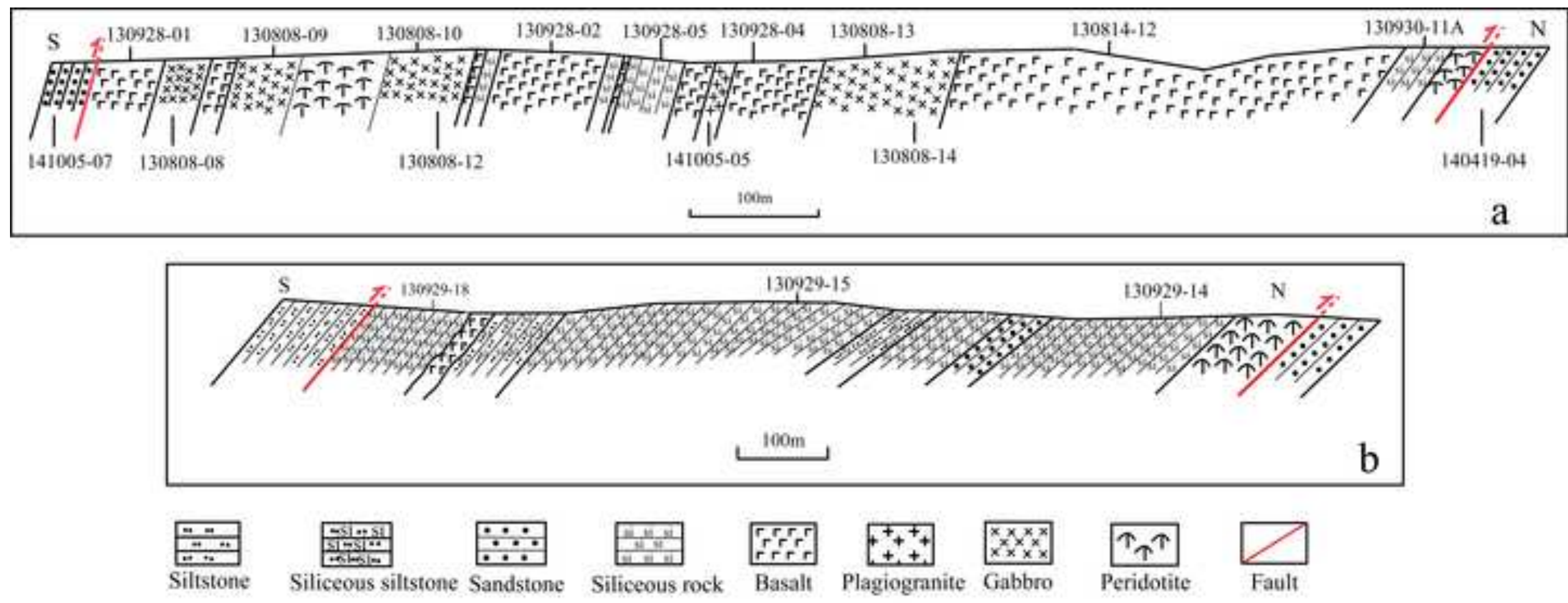


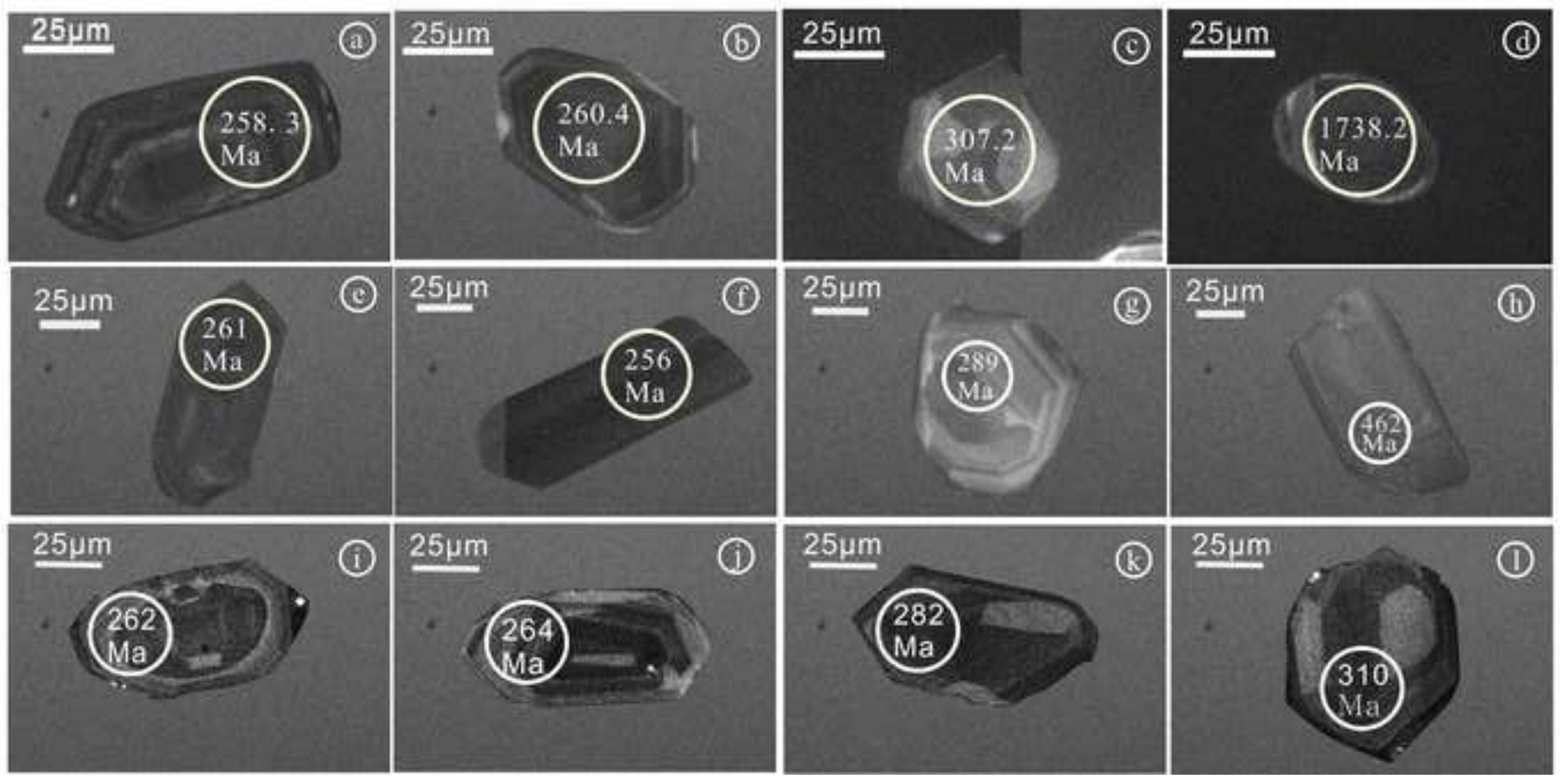



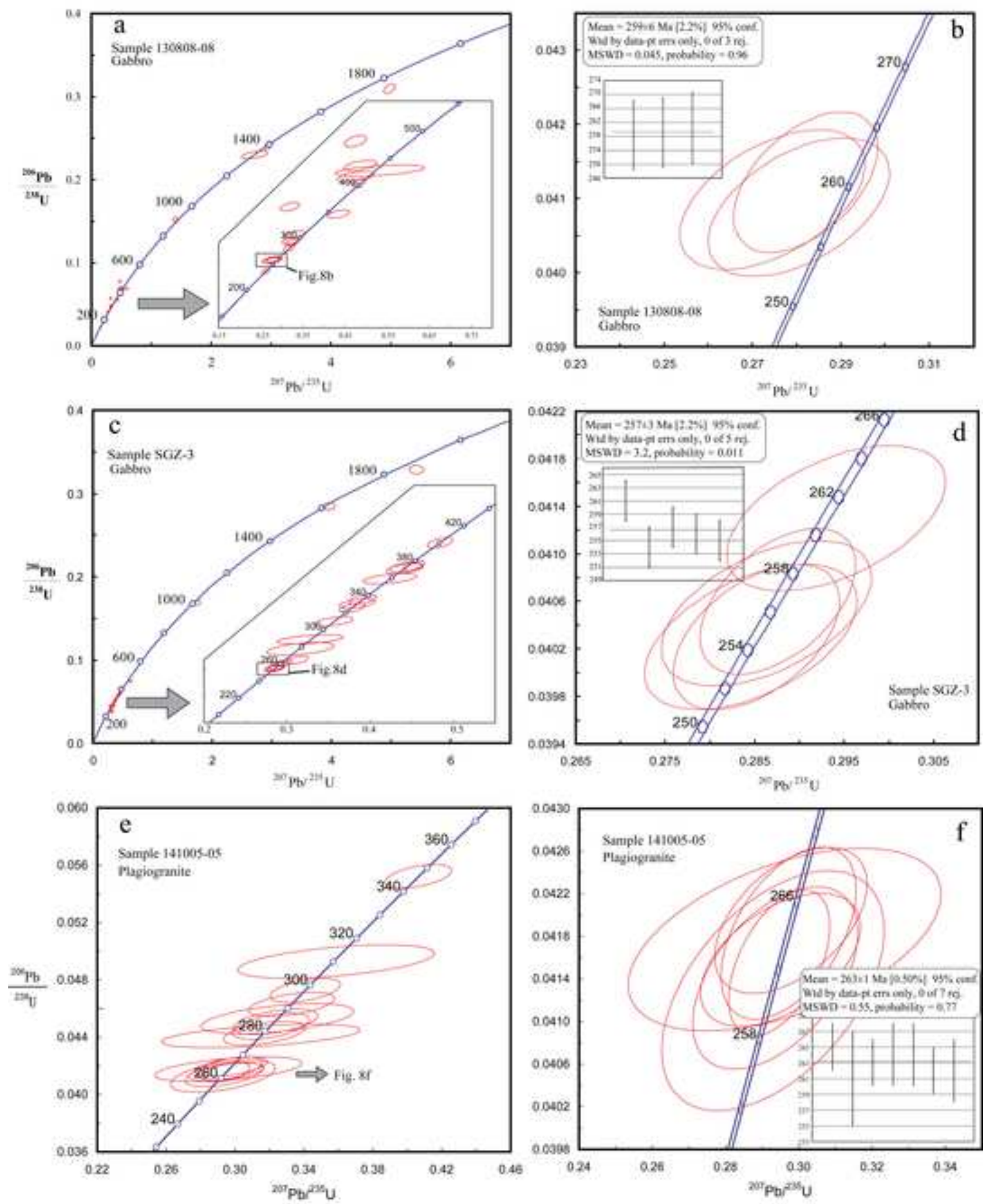


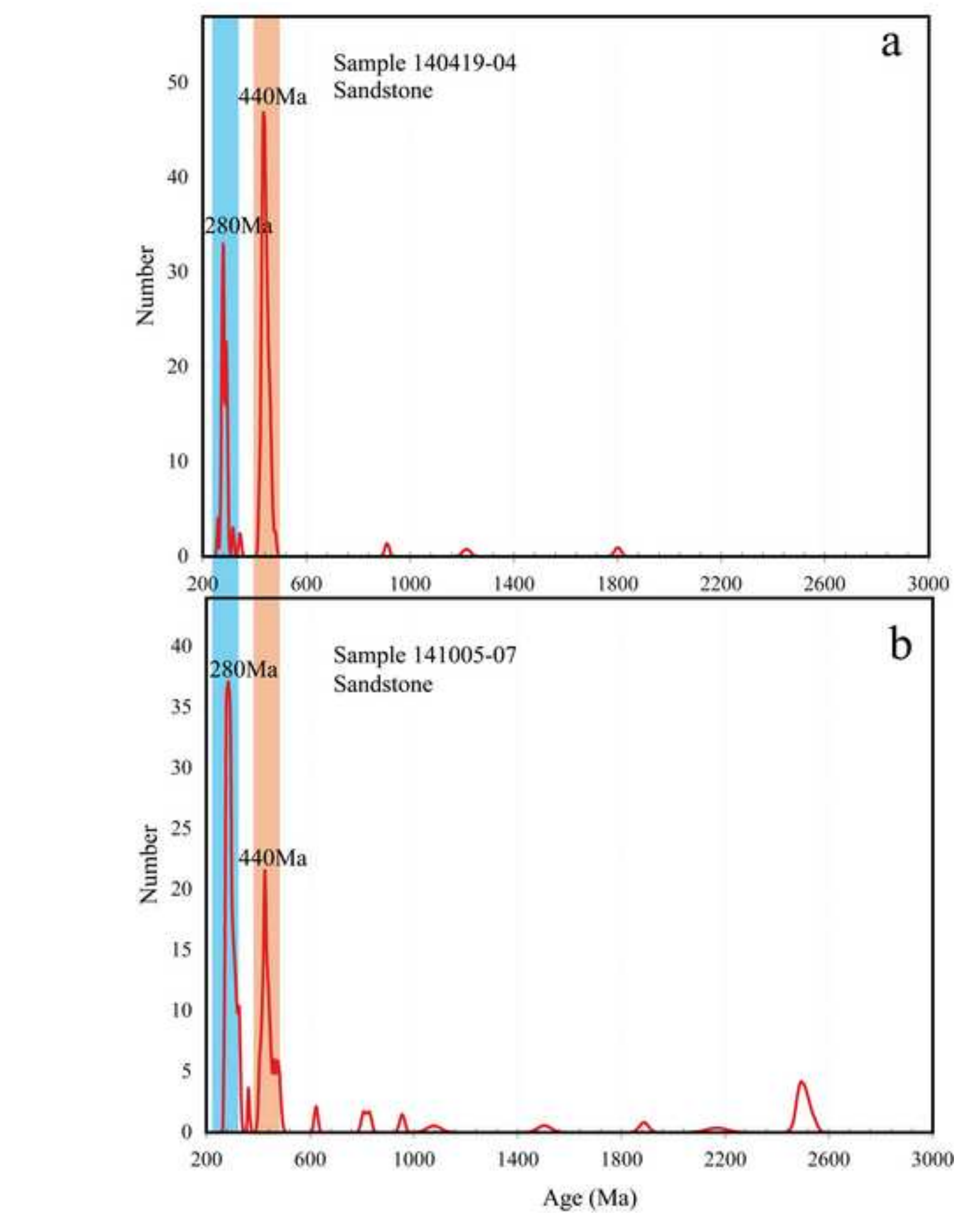

Figure

\section{Figure}



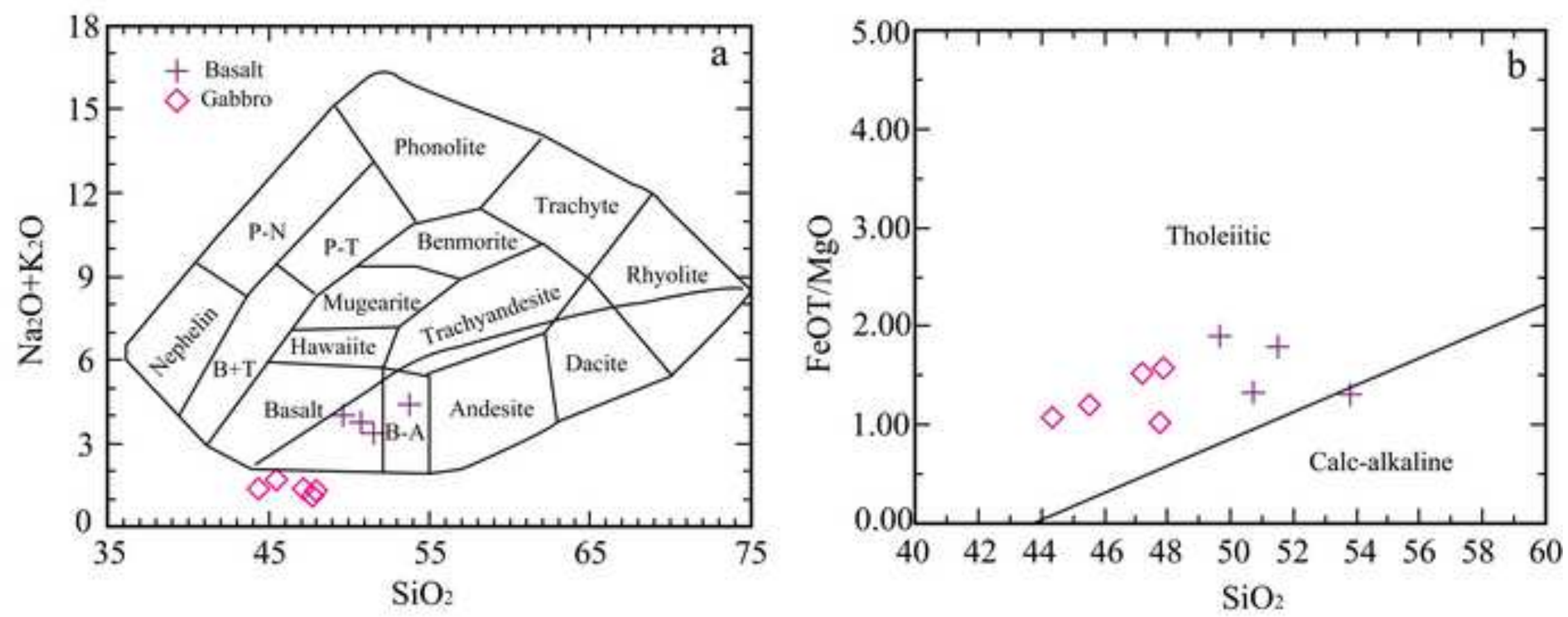

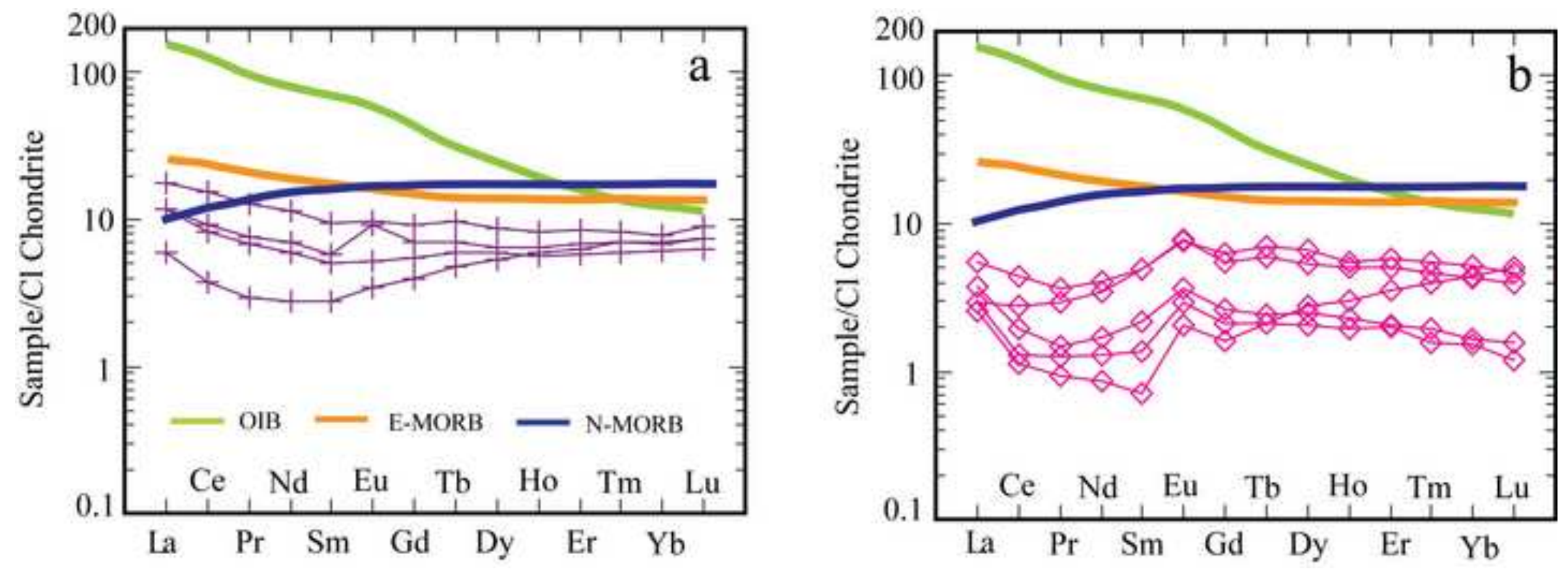

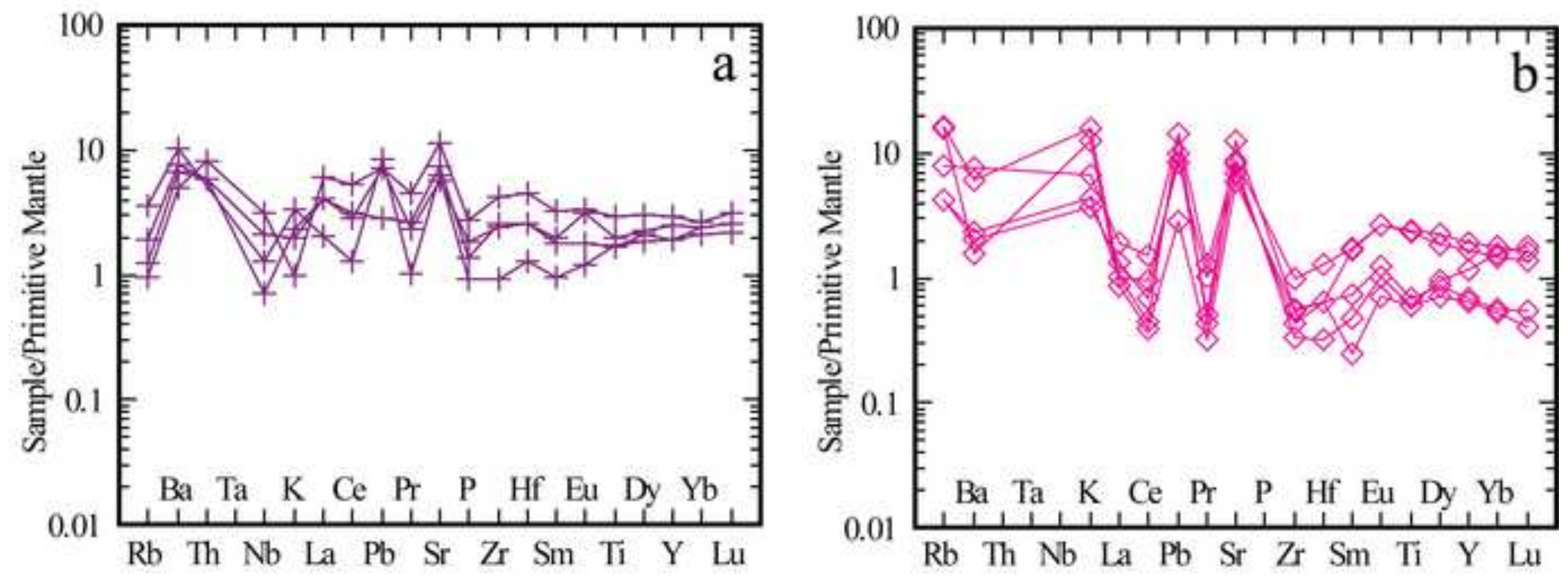

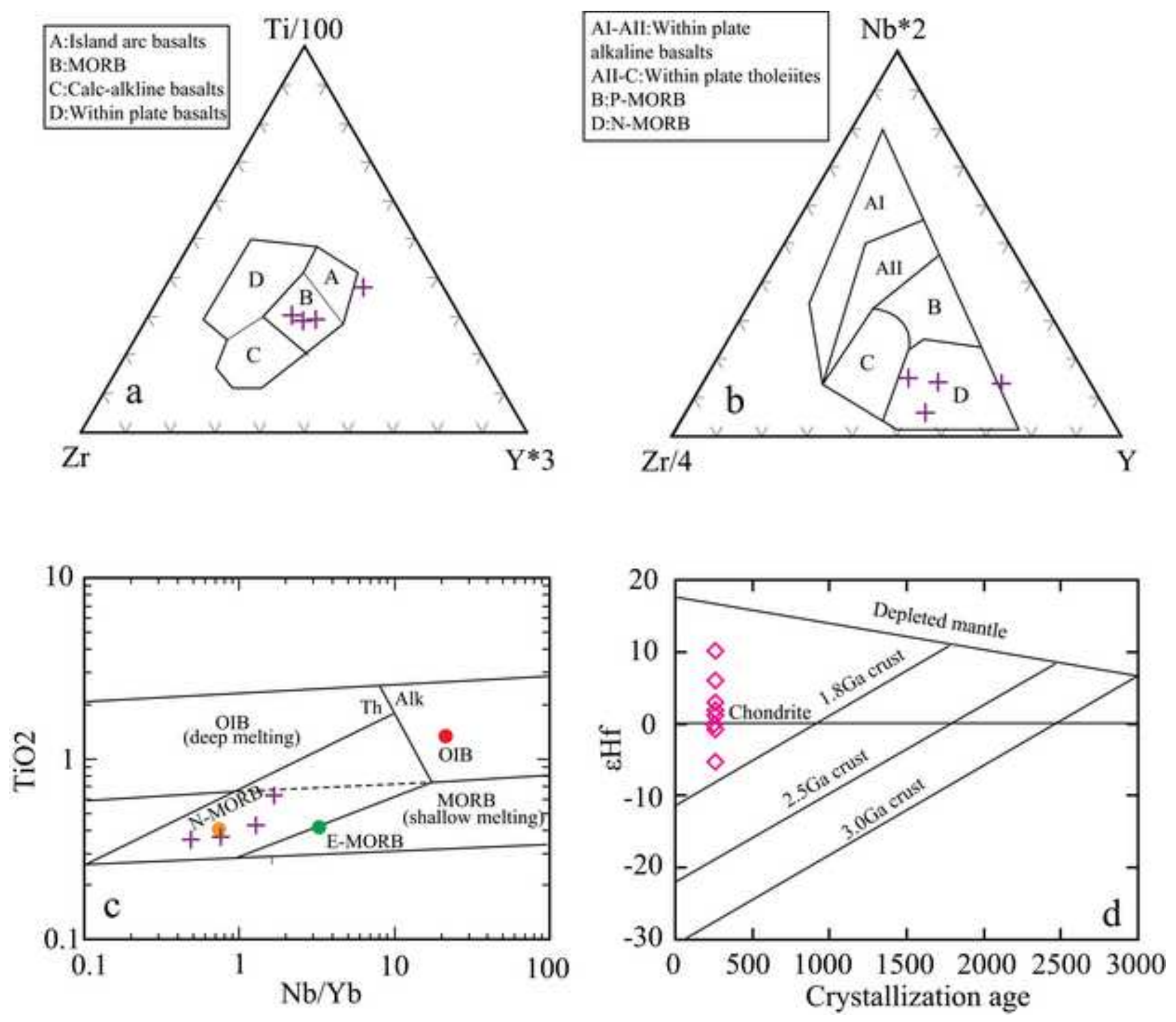

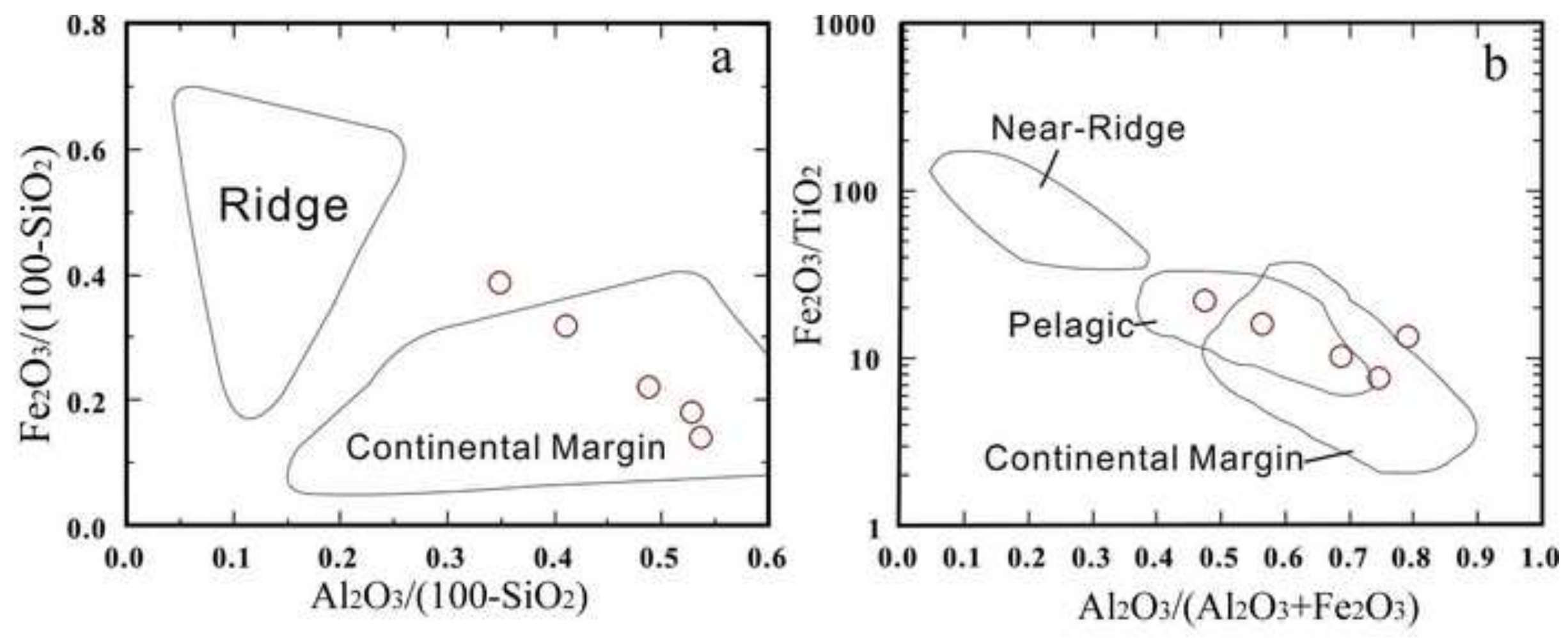
(A) Before Permian

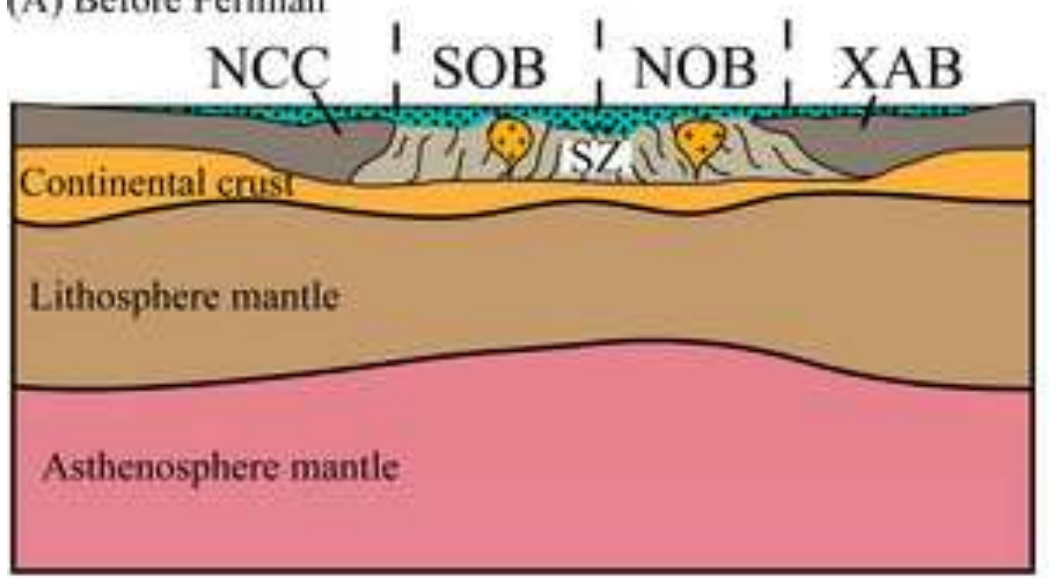

\section{(B) Early Permian}
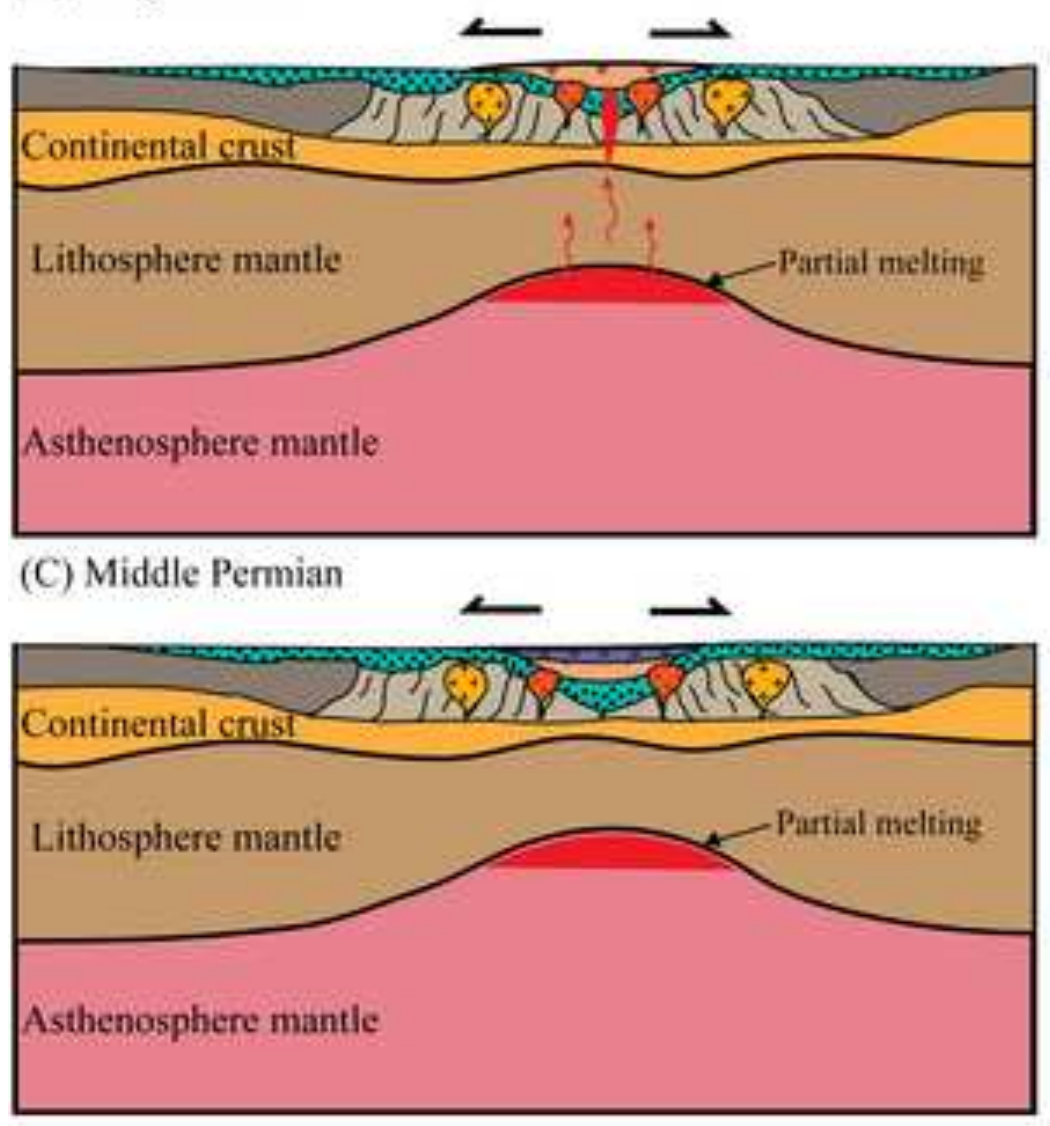

(D) Late Permian

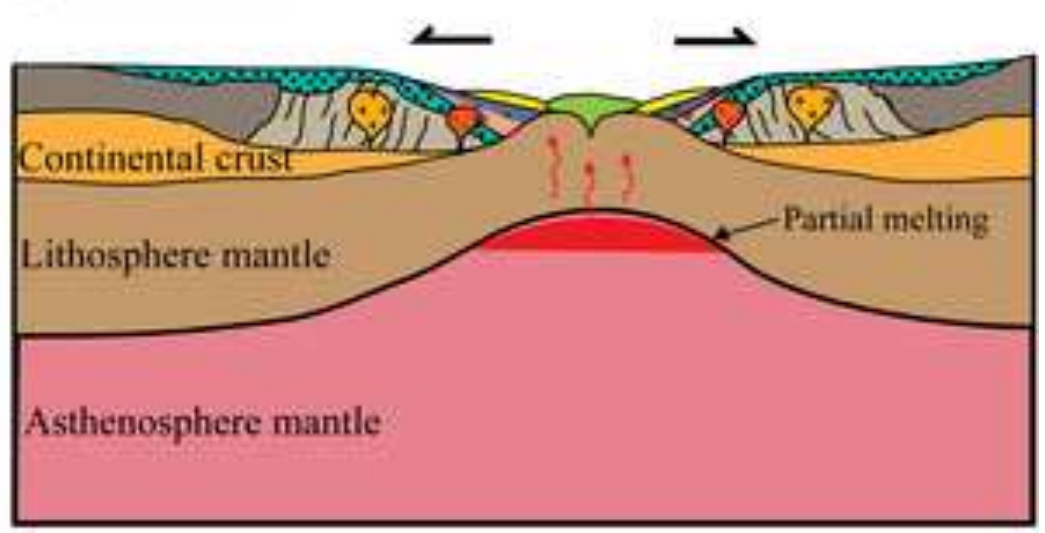

(E) After Permian

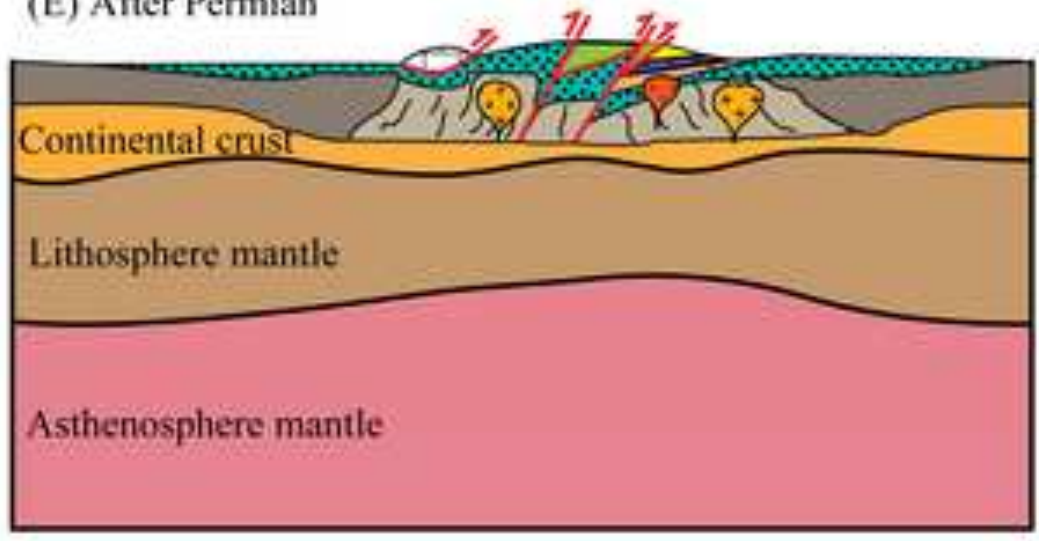

Turbidite
W Zlesi Formation Early Paleozoic arc pluton
C] Early Paleozoic orogenic terrane

Late Carboniferous-Early Permian strata

洍年 Limestone nappe of Amushan Formation

$\square$ Solonker ophiolite

Fault

$\square$ Dashizhai Formation

P Early Permian plutonic rocks 
Table 1. SIMS zircon U-Pb data of gabbro sample 130808-08 from the Solonker ophiolite.

\begin{tabular}{ccccccccc}
\hline \multirow{2}{*}{ Spot } & Concentritions $(\mathrm{ppm})$ & \multicolumn{7}{c}{ Isotopic ratios } \\
\cline { 2 - 9 } & $\mathrm{U}$ & $\mathrm{Th}$ & $\mathrm{Pb}$ & $\mathrm{Th} / \mathrm{U}$ & ${ }^{207} \mathrm{~Pb} /{ }^{235} \mathrm{U}$ & $1 \sigma \%$ & ${ }^{206} \mathrm{~Pb} /{ }^{238} \mathrm{U}$ & $1 \sigma \%$ \\
\hline 130808-08@4 & 2016 & 1630 & 97 & 0.809 & 0.26179 & 2.23 & 0.0374 & 1.51 \\
$130808-08 @ 1$ & 3328 & 2098 & 162 & 0.630 & 0.28056 & 4.82 & 0.0409 & 1.51 \\
$130808-08 @ 10$ & 585 & 1349 & 42 & 2.307 & 0.27455 & 5.04 & 0.0410 & 1.52 \\
$130808-08 @ 11$ & 825 & 1515 & 56 & 1.836 & 0.28211 & 3.81 & 0.0412 & 1.52 \\
$130808-08 @ 2$ & 906 & 245 & 46 & 0.271 & 0.31707 & 2.71 & 0.0447 & 1.54 \\
$130808-08 @ 17$ & 703 & 350 & 39 & 0.498 & 0.32525 & 3.02 & 0.0463 & 1.51 \\
$130808-08 @ 5$ & 928 & 408 & 51 & 0.440 & 0.32110 & 4.15 & 0.0469 & 1.51 \\
$130808-08 @ 19$ & 673 & 463 & 41 & 0.688 & 0.32966 & 5.13 & 0.0488 & 1.50 \\
$130808-08 @ 13$ & 1305 & 1108 & 91 & 0.849 & 0.43458 & 4.02 & 0.0551 & 1.51 \\
$130808-08 @ 7$ & 1909 & 2711 & 138 & 1.420 & 0.31918 & 4.75 & 0.0573 & 1.50 \\
$130808-08 @ 6$ & 955 & 195 & 69 & 0.205 & 0.48410 & 2.04 & 0.0647 & 1.50 \\
$130808-08 @ 9$ & 499 & 336 & 42 & 0.675 & 0.47627 & 6.01 & 0.0667 & 1.56 \\
$130808-08 @ 18$ & 1115 & 1376 & 109 & 1.234 & 0.53330 & 13.12 & 0.0686 & 1.65 \\
$130808-08 @ 15$ & 626 & 355 & 54 & 0.568 & 0.48714 & 5.33 & 0.0701 & 1.51 \\
$130808-08 @ 14$ & 1531 & 722 & 137 & 0.472 & 0.47589 & 3.61 & 0.0776 & 1.50 \\
$130808-08 @ 16$ & 1275 & 182 & 214 & 0.143 & 1.39644 & 2.37 & 0.1526 & 1.50 \\
$130808-08 @ 12$ & 258 & 398 & 83 & 1.543 & 2.72486 & 6.57 & 0.2298 & 1.54 \\
$130808-08 @ 3$ & 2680 & 1295 & 795 & 0.483 & 2.95023 & 1.55 & 0.2403 & 1.50 \\
$130808-08 @ 20$ & 1393 & 30 & 484 & 0.022 & 4.97661 & 1.57 & 0.3095 & 1.51 \\
\hline & & & & & & & & \\
\hline
\end{tabular}

Table 1. (Continued)

\begin{tabular}{|c|c|c|c|c|c|c|}
\hline \multicolumn{6}{|l|}{ Age(Ma) } & \multirow{2}{*}{$\begin{array}{c}\text { Concordanty } \\
\%\end{array}$} \\
\hline${ }^{207} \mathrm{~Pb} /{ }^{206} \mathrm{~Pb}$ & $1 \sigma \%$ & ${ }^{207} \mathrm{~Pb} /{ }^{235} \mathrm{U}$ & $1 \sigma \%$ & ${ }^{206} \mathrm{~Pb} /{ }^{238} \mathrm{U}$ & $1 \sigma \%$ & \\
\hline 231.4 & 37.5 & 236.1 & 4.7 & 236.6 & 3.5 & -0.21 \\
\hline 184.2 & 103.3 & 251.1 & 10.8 & 258.3 & 3.8 & -2.79 \\
\hline 127.7 & 109.3 & 246.3 & 11.1 & 258.9 & 3.9 & -4.87 \\
\hline 178 & 79.6 & 252.3 & 8.6 & 260.4 & 3.9 & -3.11 \\
\hline 262.2 & 50.3 & 279.6 & 6.6 & 281.7 & 4.2 & -0.75 \\
\hline 237.8 & 59.2 & 285.9 & 7.5 & 291.9 & 4.3 & -2.06 \\
\hline 178.3 & 87.7 & 282.8 & 10.3 & 295.5 & 4.4 & -4.30 \\
\hline 146.8 & 111.1 & 289.3 & 13 & 307.2 & 4.5 & -5.83 \\
\hline 499.5 & 80.1 & 366.4 & 12.4 & 345.7 & 5.1 & 5.99 \\
\hline-327 & 112.1 & 281.3 & 11.7 & 359.4 & 5.2 & -21.73 \\
\hline 382.4 & 30.7 & 400.9 & 6.8 & 404.1 & 5.9 & -0.79 \\
\hline 277.2 & 127.8 & 395.5 & 19.9 & 416 & 6.3 & -4.93 \\
\hline
\end{tabular}




\begin{tabular}{ccccccl}
468.6 & 264.9 & 434 & 47.4 & 427.5 & 6.8 & 1.52 \\
214.5 & 114.4 & 403 & 17.9 & 436.6 & 6.4 & -7.70 \\
-85.3 & 78.7 & 395.2 & 11.9 & 482 & 7 & -18.01 \\
818.5 & 37.8 & 887.4 & 14.1 & 915.3 & 12.8 & -3.05 \\
1338.1 & 118.7 & 1335.3 & 50 & 1333.5 & 18.6 & 0.34 \\
1405 & 7.7 & 1394.9 & 11.9 & 1388.3 & 18.8 & 1.20 \\
1905.1 & 7.7 & 1815.4 & 13.3 & 1738.2 & 23 & 9.60 \\
\hline
\end{tabular}


Table 2. LA-ICP-MS zircon U-Pb data of gabbro sample SGZ-3 from the Solonker ophiolite

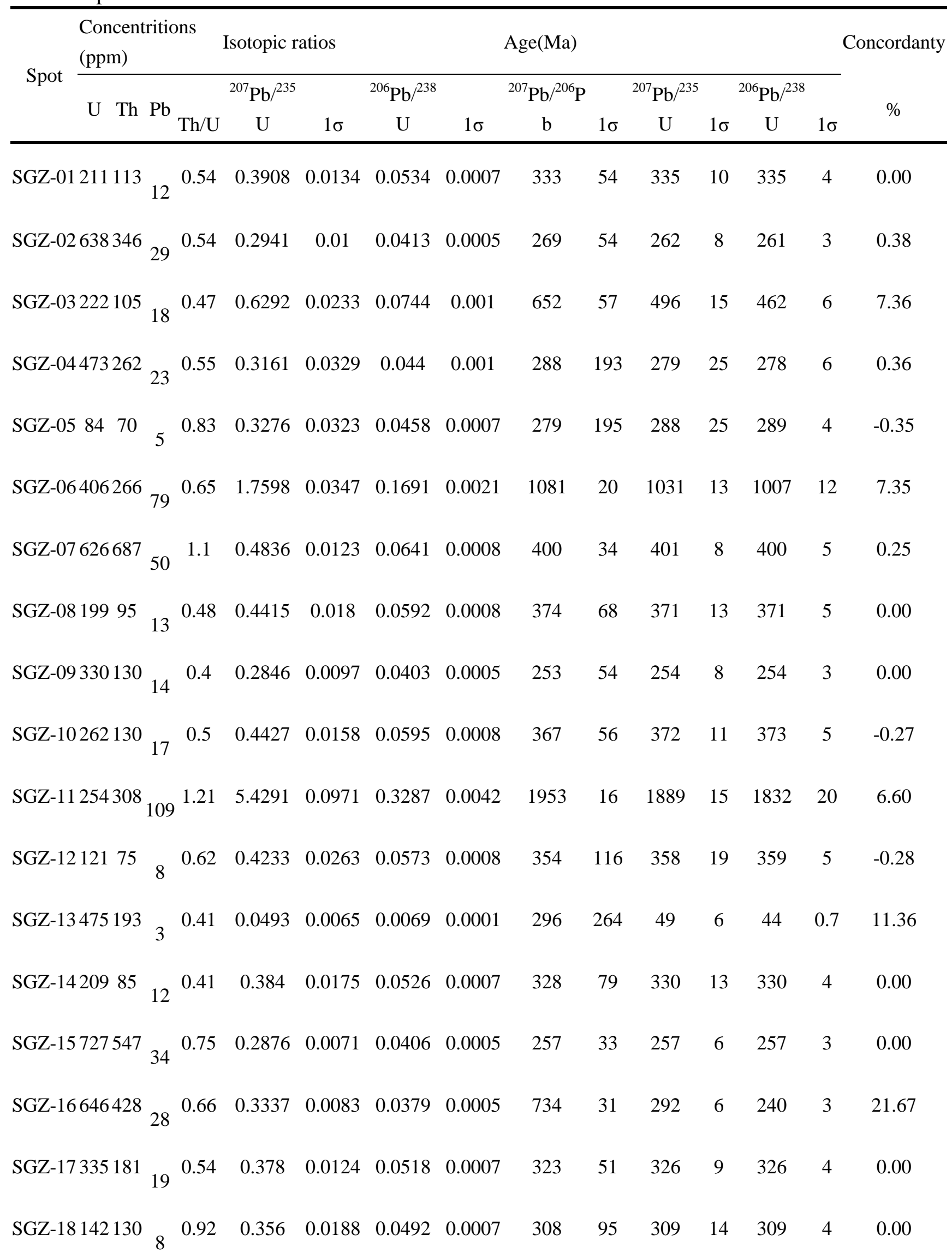




\begin{tabular}{|c|c|c|c|c|c|c|c|c|c|c|c|c|c|}
\hline SGZ-19 177187 & 64 & 1.05 & 3.9654 & 0.0745 & 0.2847 & 0.0036 & 1642 & 18 & 1627 & 15 & 1615 & 18 & 1.67 \\
\hline SGZ-20 565291 & 37 & 0.52 & 0.4524 & 0.0105 & 0.0598 & 0.0008 & 406 & 30 & 379 & 7 & 374 & 5 & 1.34 \\
\hline SGZ-21 580409 & 26 & 0.71 & 0.2937 & 0.0137 & 0.038 & 0.0005 & 455 & 111 & 261 & 11 & 240 & 3 & 8.75 \\
\hline SGZ-22 482529 & 24 & 1.1 & 0.2863 & 0.0096 & 0.0405 & 0.0005 & 254 & 54 & 256 & 8 & 256 & 3 & 0.00 \\
\hline SGZ-23 209187 & 10 & 0.9 & 0.3124 & 0.0106 & 0.0419 & 0.0006 & 371 & 52 & 276 & 8 & 265 & 3 & 4.15 \\
\hline SGZ-24 431205 & 19 & 0.48 & 0.2852 & 0.0076 & 0.0403 & 0.0005 & 255 & 37 & 255 & 6 & 255 & 3 & 0.00 \\
\hline
\end{tabular}


Table 3. LA-ICP-MS zircon U-Pb data of plagiogranite sample 141005-05 from the Solonker ophiolite.

\begin{tabular}{|c|c|c|c|c|c|c|c|c|}
\hline \multirow{2}{*}{ Spot name } & \multicolumn{8}{|c|}{ Corrected ratios } \\
\hline & ${ }^{207} \mathrm{~Pb} /{ }^{206} \mathrm{~Pb}$ & $1 \sigma$ & ${ }^{207} \mathrm{~Pb} /{ }^{235} \mathrm{U}$ & $1 \sigma$ & ${ }^{206} \mathrm{~Pb} /{ }^{238} \mathrm{U}$ & $1 \sigma$ & ${ }^{208} \mathrm{~Pb} /{ }^{232} \mathrm{Th}$ & $1 \sigma$ \\
\hline $0505-01$ & 0.05279 & 0.00693 & 0.35864 & 0.04672 & 0.04928 & 0.00095 & 0.01755 & 0.00055 \\
\hline $0505-02$ & 0.05339 & 0.00211 & 0.4064 & 0.01585 & 0.05523 & 0.00067 & 0.01844 & 0.00028 \\
\hline $0505-03$ & 0.05206 & 0.00329 & 0.32351 & 0.0201 & 0.04508 & 0.00072 & 0.01477 & 0.00041 \\
\hline 0505-04 & 0.05151 & 0.00297 & 0.29786 & 0.017 & 0.04195 & 0.00056 & 0.01336 & 0.00023 \\
\hline 0505-05 & 0.05216 & 0.00323 & 0.3328 & 0.02033 & 0.04629 & 0.00069 & 0.01587 & 0.00033 \\
\hline $0505-06$ & 0.08688 & 0.00592 & 0.52457 & 0.03458 & 0.04379 & 0.00075 & 0.01298 & 0.00019 \\
\hline 0505-07 & 0.05183 & 0.00777 & 0.31496 & 0.04709 & 0.04409 & 0.00067 & 0.01631 & 0.00047 \\
\hline 0505-08 & 0.05147 & 0.00446 & 0.29297 & 0.02482 & 0.04129 & 0.00092 & 0.01395 & 0.00062 \\
\hline 0505-09 & 0.05147 & 0.00313 & 0.29502 & 0.01784 & 0.04158 & 0.00051 & 0.01295 & 0.00028 \\
\hline-10 & 0.05 & 0.00268 & 0.29723 & 0.01506 & 0.04183 & 0.00066 & 0.01375 & 0.00029 \\
\hline 0505-11 & 0.36186 & 0.00738 & 3.59384 & 0.05711 & 0.07203 & 0.00092 & 0.0186 & 0.00179 \\
\hline 0505-12 & 0.05144 & 0.0061 & 0.29614 & 0.0349 & 0.04177 & 0.0007 & 0.01252 & 0.00057 \\
\hline $0505-13$ & 0.09308 & 0.00595 & 0.57402 & 0.03451 & 0.04473 & 0.00097 & 0.01316 & 0.0003 \\
\hline $0505-14$ & 0.05146 & 0.00202 & 0.29469 & 0.01127 & 0.04155 & 0.00056 & 0.0131 & 0.00023 \\
\hline $0505-15$ & 0.08072 & 0.00369 & 0.48045 & 0.0209 & 0.04317 & 0.0006 & 0.01289 & 0.00016 \\
\hline $0505-16$ & 0.08477 & 0.00559 & 0.54997 & 0.03489 & 0.04705 & 0.00086 & 0.01398 & 0.00023 \\
\hline 0505-17 & 0.08591 & 0.00409 & 0.54611 & 0.0249 & 0.04611 & 0.00063 & 0.01368 & 0.00019 \\
\hline 0505-18 & 0.05144 & 0.0033 & 0.29361 & 0.01843 & 0.04141 & 0.0007 & 0.01358 & 0.00034 \\
\hline 0505-19 & 0.05187 & 0.00305 & 0.31554 & 0.01819 & 0.04413 & 0.00068 & 0.01413 & 0.00034 \\
\hline 0505-20 & 0.07793 & 0.00493 & 0.45865 & 0.02798 & 0.04269 & 0.00072 & 0.0128 & 0.00018 \\
\hline $0505-21$ & 0.05196 & 0.00324 & 0.31713 & 0.01942 & 0.04428 & 0.00068 & 0.01385 & 0.00047 \\
\hline $0505-22$ & 0.05872 & 0.0023 & 0.34602 & 0.01285 & 0.04274 & 0.00054 & 0.01323 & 0.00014 \\
\hline $0505-23$ & 0.05197 & 0.00304 & 0.32077 & 0.0183 & 0.04477 & 0.00075 & 0.01309 & 0.00039 \\
\hline $0505-24$ & 0.0523 & 0.00261 & 0.34082 & 0.01668 & 0.04727 & 0.00069 & 0.0157 & 0.00036 \\
\hline $0505-25$ & 0.052 & 0.00585 & 0.32462 & 0.03618 & 0.04529 & 0.00086 & 0.01568 & 0.0005 \\
\hline
\end{tabular}

Table 3. (Continued)

\begin{tabular}{ccccccccc}
\hline \multicolumn{2}{c}{ Corrected ages $(\mathrm{Ma})$} & \multicolumn{1}{c}{ Concordanty } \\
\hline${ }^{207} \mathrm{~Pb} /{ }^{206} \mathrm{~Pb}$ & $1 \sigma$ & ${ }^{207} \mathrm{~Pb} /{ }^{235} \mathrm{U}$ & $1 \sigma$ & ${ }^{206} \mathrm{~Pb} /{ }^{238} \mathrm{U}$ & $1 \sigma$ & ${ }^{208} \mathrm{~Pb} /{ }^{232} \mathrm{Th}$ & $1 \sigma$ & $(\%)$ \\
\hline 320 & 259 & 311 & 35 & 310 & 6 & 352 & 11 & 0.32 \\
345 & 66 & 346 & 11 & 347 & 4 & 369 & 6 & -0.29 \\
288 & 113 & 285 & 15 & 284 & 4 & 296 & 8 & 0.35 \\
264 & 107 & 265 & 13 & 265 & 3 & 268 & 5 & 0.00 \\
292 & 113 & 292 & 15 & 292 & 4 & 318 & 7 & 0.00 \\
1358 & 135 & 428 & 23 & 276 & 5 & 261 & 4 & 55.07 \\
278 & 297 & 278 & 36 & 278 & 4 & 327 & 9 & 0.00
\end{tabular}




\begin{tabular}{ccccccccc}
262 & 151 & 261 & 19 & 261 & 6 & 280 & 12 & 0.00 \\
262 & 117 & 263 & 14 & 263 & 3 & 260 & 6 & 0.00 \\
266 & 87 & 264 & 12 & 264 & 4 & 276 & 6 & 0.00 \\
3758 & 32 & 1548 & 13 & 448 & 6 & 372 & 36 & 245.54 \\
261 & 236 & 263 & 27 & 264 & 4 & 251 & 11 & -0.38 \\
1490 & 124 & 461 & 22 & 282 & 6 & 264 & 6 & 63.48 \\
261 & 63 & 262 & 9 & 262 & 3 & 263 & 5 & 0.00 \\
1215 & 92 & 398 & 14 & 272 & 4 & 259 & 3 & 46.32 \\
1310 & 132 & 445 & 23 & 296 & 5 & 281 & 5 & 50.34 \\
1336 & 94 & 442 & 16 & 291 & 4 & 275 & 4 & 51.89 \\
261 & 113 & 261 & 14 & 262 & 4 & 273 & 7 & -0.38 \\
280 & 104 & 278 & 14 & 278 & 4 & 284 & 7 & 0.00 \\
1145 & 129 & 383 & 19 & 269 & 4 & 257 & 4 & 42.38 \\
284 & 112 & 280 & 15 & 279 & 4 & 278 & 9 & 0.36 \\
557 & 88 & 302 & 10 & 270 & 3 & 266 & 3 & 11.85 \\
284 & 100 & 282 & 14 & 282 & 5 & 263 & 8 & 0.00 \\
299 & 85 & 298 & 13 & 298 & 4 & 315 & 7 & 0.00 \\
285 & 217 & 285 & 28 & 286 & 5 & 314 & 10 & -0.35 \\
\hline
\end{tabular}


Table 4. Detrital zircon $\mathrm{U}-\mathrm{Pb}$ ages of sandtones from both south and north sides of the Solonker ophiolite belt.

\begin{tabular}{|c|c|c|c|c|c|c|c|c|}
\hline \multirow{2}{*}{ Spot name } & \multicolumn{8}{|c|}{ Corrected ratios } \\
\hline & ${ }^{207} \mathrm{~Pb} /{ }^{206} \mathrm{~Pb}$ & $1 \sigma$ & ${ }^{207} \mathrm{~Pb} /{ }^{235} \mathrm{U}$ & $1 \sigma$ & ${ }^{206} \mathrm{~Pb} /{ }^{238} \mathrm{U}$ & $1 \sigma$ & ${ }^{208} \mathrm{~Pb} /{ }^{232} \mathrm{Th}$ & $1 \sigma$ \\
\hline \multicolumn{9}{|l|}{ Sample141005-07 } \\
\hline 0507-01 & 0.05178 & 0.00276 & 0.31008 & 0.01635 & 0.04343 & 0.00053 & 0.01419 & 0.0002 \\
\hline 0507-02 & 0.05561 & 0.00136 & 0.53542 & 0.01271 & 0.06982 & 0.0008 & 0.02166 & 0.0003 \\
\hline $0507-03$ & 0.05173 & 0.00178 & 0.30954 & 0.0103 & 0.04339 & 0.00057 & 0.01431 & 0.0002 \\
\hline 0507-04 & 0.05261 & 0.00256 & 0.35899 & 0.01697 & 0.04948 & 0.00076 & 0.01609 & 0.0003 \\
\hline 0507-05 & 0.05532 & 0.00133 & 0.5209 & 0.01211 & 0.06828 & 0.00077 & 0.02215 & 0.0003 \\
\hline 0507-06 & 0.05212 & 0.00213 & 0.33287 & 0.01324 & 0.04632 & 0.00065 & 0.01487 & 0.0002 \\
\hline 0507-07 & 0.05193 & 0.00402 & 0.31919 & 0.02451 & 0.04458 & 0.00061 & 0.01476 & 0.0002 \\
\hline 0507-08 & 0.05465 & 0.00298 & 0.50468 & 0.02673 & 0.06697 & 0.00088 & 0.02091 & 0.0002 \\
\hline 0507-09 & 0.07089 & 0.00158 & 1.56009 & 0.03375 & 0.15961 & 0.00186 & 0.05156 & $0.0008^{\prime}$ \\
\hline $0507-10$ & 0.05546 & 0.00124 & 0.52662 & 0.01143 & 0.06887 & 0.00076 & 0.02336 & 0.00 \\
\hline $0507-11$ & 0.05177 & 0.00153 & 0.3131 & 0.00899 & 0.04386 & 0.00053 & 0.01469 & 0.0002 \\
\hline $0507-12$ & 0.05213 & 0.01176 & 0.3341 & 0.07508 & 0.04648 & 0.00106 & 0.01723 & 0.0006 \\
\hline $0507-13$ & 0.05576 & 0.00123 & 0.54697 & 0.01171 & 0.07114 & 0.00079 & 0.02306 & 0.0003 \\
\hline 0507-14 & 0.06226 & 0.00194 & 0.87126 & 0.02539 & 0.10149 & 0.00112 & 0.03121 & 0.0003 \\
\hline 0507-15 & 0.05537 & 0.00109 & 0.52066 & 0.00988 & 0.0682 & 0.00073 & 0.02149 & 0.0003 \\
\hline 0507-16 & 0.16312 & 0.00255 & 10.596 & 0.16102 & 0.47115 & 0.00522 & 0.13641 & 0.0022 \\
\hline 0507-17 & 0.16254 & 0.00354 & 10.5164 & 0.22602 & 0.46928 & 0.00634 & 0.12794 & 0.0025 \\
\hline 0507-18 & 0.05537 & 0.00155 & 0.52175 & 0.01417 & 0.06835 & 0.00082 & 0.02262 & 0.0004 \\
\hline 0507-19 & 0.05247 & 0.00206 & 0.35101 & 0.01351 & 0.04852 & 0.00061 & 0.01567 & 0.0002 \\
\hline 0507-20 & 0.05238 & 0.00156 & 0.34631 & 0.01001 & 0.04795 & 0.00057 & 0.01555 & 0.0002 \\
\hline $0507-21$ & 0.05275 & 0.00125 & 0.36676 & 0.00838 & 0.05043 & 0.00057 & 0.01579 & 0.0002 \\
\hline $0507-22$ & 0.06846 & 0.00256 & 0.68436 & 0.02497 & 0.07251 & 0.00094 & 0.02845 & 0.0005 \\
\hline $0507-23$ & 0.05183 & 0.00226 & 0.31469 & 0.01336 & 0.04404 & 0.00064 & 0.01398 & $0.0002^{\prime}$ \\
\hline $0507-24$ & 0.05221 & 0.00171 & 0.33498 & 0.01065 & 0.04653 & 0.00058 & 0.01518 & 0.0003 \\
\hline $0507-25$ & 0.05192 & 0.00169 & 0.31781 & 0.01008 & 0.0444 & 0.00055 & 0.01455 & 0.0002 \\
\hline $0507-26$ & 0.05203 & 0.00234 & 0.32571 & 0.01429 & 0.04541 & 0.00064 & 0.01416 & 0.0003 \\
\hline $0507-27$ & 0.07587 & 0.0023 & 0.60559 & 0.01703 & 0.05789 & 0.00065 & 0.01741 & 0.0001 \\
\hline $0507-28$ & 0.05636 & 0.0014 & 0.58019 & 0.014 & 0.07467 & 0.00085 & 0.02362 & 0.0004 \\
\hline 0507-29 & 0.05657 & 0.00167 & 0.5972 & 0.01708 & 0.07657 & 0.00095 & 0.02339 & 0.0004 \\
\hline 0507-30 & 0.05195 & 0.00173 & 0.32046 & 0.01038 & 0.04475 & 0.00056 & 0.01417 & .0002 \\
\hline $0507-31$ & 0.05525 & 0.00139 & 0.5159 & 0.01261 & 0.06773 & 0.00078 & 0.02266 & 0.0004 \\
\hline $0507-32$ & 0.05664 & 0.00186 & 0.59798 & 0.01904 & 0.07659 & 0.00099 & 0.02851 & 0.000 \\
\hline 0507-33 & 0.05206 & 0.00139 & 0.32869 & 0.00854 & 0.0458 & 0.00053 & 0.01471 & 0.0002 \\
\hline 0507-34 & 0.16548 & 0.0027 & 10.87376 & 0.17301 & 0.47666 & 0.00526 & 0.13676 & $0.0024^{\prime}$ \\
\hline
\end{tabular}




\begin{tabular}{|c|c|c|c|c|c|c|c|c|}
\hline 0507-35 & 0.05553 & 0.00183 & 0.53118 & 0.01716 & 0.06939 & 0.00082 & 0.02313 & 0.0 \\
\hline 0507-36 & 0.16434 & 0.003 & 10.73776 & 0.19211 & 0.47397 & 0.00569 & 0.1267 & 0.0 \\
\hline 0507-37 & 0.05212 & 0.00232 & 0.33227 & 0.01439 & 0.04625 & 0.00067 & 0.01543 & 0.0 \\
\hline 0507-38 & 0.05237 & 0.00374 & 0.34523 & 0.02439 & 0.04782 & 0.00072 & 0.01591 & 0 \\
\hline 0507-39 & 0.05294 & 0.00205 & 0.37801 & 0.0143 & 0.05179 & 0.00066 & 0.01718 & 0 \\
\hline 0507-40 & 0.05167 & 0.00208 & 0.30537 & 0.01209 & 0.04287 & 0.00054 & 0.01447 & 0 \\
\hline $0507-41$ & 0.0522 & 0.00269 & 0.33668 & 0.01716 & 0.04679 & 0.00059 & 0.01488 & \\
\hline 0507-42 & 0.16821 & 0.00309 & 11.20126 & 0.2017 & 0.48306 & 0.00577 & 0.1399 & \\
\hline $0507-43$ & 0.05203 & 0.00211 & 0.32438 & 0.01277 & 0.04523 & 0.00062 & 0.0151 & \\
\hline $0507-44$ & 0.16276 & 0.0027 & 10.54478 & 0.17012 & 0.46999 & 0.00506 & 0.14096 & 0.0 \\
\hline $0507-45$ & 0.05269 & 0.00197 & 0.36562 & 0.01329 & 0.05034 & 0.00067 & 0.01573 & 0 \\
\hline 0507-46 & 0.0523 & 0.00155 & 0.34317 & 0.00991 & 0.0476 & 0.00057 & 0.01567 & \\
\hline $0507-47$ & 0.05219 & 0.00299 & 0.32097 & 0.01813 & 0.04462 & 0.00063 & 0.01523 & 0.0 \\
\hline 0507-48 & 0.05619 & 0.00143 & 0.57145 & 0.0141 & 0.07378 & 0.00086 & 0.02348 & 0 . \\
\hline 0507-49 & 0.05504 & 0.00259 & 0.50149 & 0.0232 & 0.0661 & 0.0009 & 0.0212 & 0 \\
\hline 0507-50 & 0.1659 & 0.00291 & 10.9306 & 0.18722 & 0.478 & 0.00525 & 0.13568 & 0. \\
\hline $0507-51$ & 0.05411 & 0.00314 & 0.32877 & 0.01875 & 0.04408 & 0.00067 & 0.01412 & 0.00 \\
\hline $0507-52$ & 0.11546 & 0.00217 & 5.41805 & 0.09923 & 0.34044 & 0.0038 & 0.09837 & 0.00 \\
\hline 0507-53 & 0.05495 & 0.00156 & 0.49674 & 0.01371 & 0.06558 & 0.0008 & 0.02157 & 0. \\
\hline $0507-54$ & 0.05528 & 0.00169 & 0.51569 & 0.01535 & 0.06768 & 0.00083 & 0.02185 & \\
\hline 0507-55 & 0.05545 & 0.00142 & 0.526 & 0.01315 & 0.06882 & 0.00078 & 0.02222 & \\
\hline 0507-56 & 0.05812 & 0.00208 & 0.39527 & 0.01388 & 0.04934 & 0.00061 & 0.01668 & \\
\hline $0507-57$ & 0.05216 & 0.0028 & 0.33262 & 0.01756 & 0.04626 & 0.00066 & 0.01599 & \\
\hline $0507-58$ & 0.05298 & 0.00189 & 0.38053 & 0.01328 & 0.05211 & 0.00066 & 0.01831 & 0 . \\
\hline 0507-59 & 0.0668 & 0.00248 & 1.22634 & 0.04314 & 0.13315 & 0.00157 & 0.04062 & 0.0 \\
\hline 0507-60 & 0.05256 & 0.00582 & 0.35683 & 0.03911 & 0.04925 & 0.00098 & 0.01704 & 0.00 \\
\hline 0507-61 & 0.05196 & 0.00504 & 0.31929 & 0.0308 & 0.04458 & 0.00067 & 0.0138 & 0.0 \\
\hline 0507-62 & 0.05497 & 0.00182 & 0.48997 & 0.01588 & 0.06467 & 0.00079 & 0.02036 & \\
\hline 0507-63 & 0.05974 & 0.00288 & 0.64358 & 0.0305 & 0.07816 & 0.00111 & 0.02236 & \\
\hline 0507-64 & 0.07531 & 0.00176 & 1.88411 & 0.0429 & 0.1815 & 0.00214 & 0.05572 & \\
\hline $0507-65$ & 0.05202 & 0.00207 & 0.32425 & 0.01262 & 0.04522 & 0.0006 & 0.01525 & 0.0 \\
\hline 0507-66 & 0.05175 & 0.00254 & 0.31158 & 0.01506 & 0.04368 & 0.00058 & 0.01371 & \\
\hline 0507-67 & 0.06951 & 0.0018 & 1.31381 & 0.0307 & 0.13707 & 0.00152 & 0.04163 & 0.00 \\
\hline 0507-68 & 0.05233 & 0.00261 & 0.33348 & 0.01633 & 0.04623 & 0.00066 & 0.01448 & 0.0 \\
\hline 0507-69 & 0.05204 & 0.00244 & 0.32609 & 0.01487 & 0.04546 & 0.00068 & 0.01446 & 0.0 \\
\hline 0507-70 & 0.09375 & 0.00225 & 3.31518 & 0.07766 & 0.25656 & 0.00308 & 0.07307 & 0.0 \\
\hline 0507-71 & 0.13534 & 0.00307 & 7.17551 & 0.14231 & 0.38453 & 0.00421 & 0.10891 & 0.0 \\
\hline 0507-72 & 0.053 & 0.00268 & 0.38087 & 0.01885 & 0.05214 & 0.00077 & 0.01694 & 0.00 \\
\hline $0507-73$ & 0.05575 & 0.00138 & 0.54435 & 0.01314 & 0.07085 & 0.00082 & 0.02344 & 0.00 \\
\hline 0507-74 & 0.05238 & 0.00428 & 0.33064 & 0.02678 & 0.0458 & 0.00068 & 0.01484 & 0.0 \\
\hline
\end{tabular}


0507-75

0.05579

0.0017

0.54684

0.01622

0.07111

0.00088

0.02317

0.0005

Sample140419-04

\begin{tabular}{|c|c|c|c|c|c|c|c|c|}
\hline 1904-01 & 0.05541 & 0.0012 & 0.52596 & 0.0108 & 0.06887 & 0.0007 & 0.02314 & 0.0003 \\
\hline 1904-02 & 0.05541 & 0.0009 & 0.52682 & 0.00797 & 0.06898 & 0.00065 & 0.02164 & 0.00 \\
\hline 1904-03 & 0.05171 & 0.00142 & 0.30715 & 0.00811 & 0.04309 & 0.00046 & 0.01381 & 0.00 \\
\hline 1904-04 & 0.05627 & 0.00197 & 0.57878 & 0.01955 & 0.07462 & 0.00093 & 0.02445 & 0.000 \\
\hline 1904-05 & 0.06939 & 0.00145 & 1.45205 & 0.02867 & 0.15181 & 0.00161 & 0.04727 & 0.000 \\
\hline 1904-06 & 0.05578 & 0.00139 & 0.54722 & 0.01301 & 0.07116 & 0.00076 & 0.02251 & 0.000 \\
\hline 1904-07 & 0.05614 & 0.00155 & 0.56855 & 0.015 & 0.07347 & 0.00082 & 0.0223 & 0.00 \\
\hline 1904-08 & 0.056 & 0.00121 & 0.56254 & 0.01154 & 0.07287 & 0.00074 & 0.02284 & 0.000 \\
\hline 1904-09 & 0.0522 & 0.00146 & 0.33345 & 0.00898 & 0.04634 & 0.0005 & 0.01592 & 0.00 \\
\hline 1904-10 & 0.05196 & 0.00428 & 0.32321 & 0.02627 & 0.04512 & 0.00075 & 0.01452 & 0.0 \\
\hline 1904-11 & 0.05576 & 0.00155 & 0.54466 & 0.01453 & 0.07086 & 0.0008 & 0.02308 & 0.00 \\
\hline 1904-12 & 0.05551 & 0.00161 & 0.53233 & 0.01482 & 0.06957 & 0.00079 & 0.02246 & 0.000 \\
\hline 1904-13 & 0.05182 & 0.00142 & 0.31396 & 0.00824 & 0.04396 & 0.00047 & 0.01477 & 0.000 \\
\hline 1904-14 & 0.05387 & 0.0035 & 0.50086 & 0.03195 & 0.06746 & 0.00105 & 0.0194 & 0.000 \\
\hline $1904-15$ & 0.05154 & 0.00215 & 0.29018 & 0.01173 & 0.04084 & 0.00055 & 0.01378 & 0.0 \\
\hline $1904-16$ & 0.07345 & 0.00171 & 0.78339 & 0.01722 & 0.07737 & 0.00083 & 0.02798 & 0.000 \\
\hline 1904-17 & 0.05208 & 0.00227 & 0.32933 & 0.01391 & 0.04587 & 0.00063 & 0.01458 & 0.000 \\
\hline 1904-18 & 0.05542 & 0.00119 & 0.52555 & 0.01066 & 0.0688 & 0.0007 & 0.02196 & 0.000 \\
\hline 1904-19 & 0.05277 & 0.002 & 0.36665 & 0.01348 & 0.05041 & 0.00061 & 0.01679 & 0.000 \\
\hline 1904-20 & 0.05127 & 0.00168 & 0.32168 & 0.01014 & 0.04551 & 0.00053 & 0.01522 & 0.000 \\
\hline 1904-21 & 0.05571 & 0.00322 & 0.54269 & 0.03034 & 0.07066 & 0.0013 & 0.02209 & 0.00 \\
\hline 1904-22 & 0.05554 & 0.00121 & 0.55082 & 0.01141 & 0.07195 & 0.00073 & 0.02338 & 0.00 \\
\hline 1904-23 & 0.05541 & 0.00144 & 0.52429 & 0.01301 & 0.06864 & 0.00074 & 0.02191 & 0.000 \\
\hline 1904-24 & 0.05512 & 0.00153 & 0.51153 & 0.01367 & 0.06732 & 0.00073 & 0.02152 & 0.00 \\
\hline $1904-25$ & 0.05217 & 0.00177 & 0.33431 & 0.01094 & 0.04649 & 0.00056 & 0.01546 & 0.000 \\
\hline 1904-26 & 0.05222 & 0.00154 & 0.33416 & 0.00947 & 0.04642 & 0.00052 & 0.01498 & 0.00 \\
\hline 1904-27 & 0.05591 & 0.0019 & 0.55401 & 0.01829 & 0.07188 & 0.00078 & 0.02306 & 0.000 \\
\hline 1904-28 & 0.0561 & 0.00215 & 0.56618 & 0.02096 & 0.07322 & 0.00095 & 0.02307 & 0.000 \\
\hline 1904-29 & 0.05526 & 0.00137 & 0.53004 & 0.01262 & 0.06958 & 0.00072 & 0.02295 & 0.000 \\
\hline 1904-30 & 0.05189 & 0.00237 & 0.3191 & 0.0142 & 0.04461 & 0.00056 & 0.01398 & 0.00 \\
\hline 1904-31 & 0.05598 & 0.00145 & 0.56047 & 0.01394 & 0.07264 & 0.00078 & 0.02259 & 0.000 \\
\hline 1904-32 & 0.05554 & 0.00198 & 0.52997 & 0.0182 & 0.06922 & 0.00088 & 0.0229 & 0.000 \\
\hline 1904-33 & 0.05636 & 0.00203 & 0.57741 & 0.02006 & 0.07433 & 0.00097 & 0.024 & 0.00 \\
\hline 1904-34 & 0.05555 & 0.0015 & 0.53258 & 0.01378 & 0.06955 & 0.00075 & 0.02287 & 0.000 \\
\hline 1904-35 & 0.05546 & 0.00148 & 0.52969 & 0.01346 & 0.06928 & 0.00076 & 0.02104 & 0.000 \\
\hline 1904-36 & 0.05561 & 0.00269 & 0.53613 & 0.02546 & 0.06993 & 0.00087 & 0.02482 & 0.00 \\
\hline 1904-37 & 0.05559 & 0.00152 & 0.54856 & 0.01446 & 0.07159 & 0.00076 & 0.02264 & 0.00 \\
\hline
\end{tabular}




\begin{tabular}{|c|c|c|c|c|c|c|c|c|}
\hline 1904-38 & 0.05187 & 0.00172 & 0.31696 & 0.01017 & 0.04433 & 0.00049 & 0.01436 & 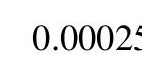 \\
\hline 1904-39 & 0.05184 & 0.00181 & 0.31598 & 0.01064 & 0.04422 & 0.00054 & 0.01418 & 0.00 \\
\hline $1904-40$ & 0.0518 & 0.00191 & 0.3138 & 0.0112 & 0.04394 & 0.00052 & 0.0141 & 0.00 \\
\hline 1904-41 & 0.08083 & 0.00134 & 2.31501 & 0.03558 & 0.20776 & 0.00203 & 0.06333 & 0.00 \\
\hline $1904-42$ & 0.05567 & 0.0014 & 0.54072 & 0.01295 & 0.07046 & 0.00074 & 0.02271 & 0.00 \\
\hline 1904-43 & 0.05635 & 0.00232 & 0.58261 & 0.02313 & 0.07501 & 0.00105 & 0.02351 & م \\
\hline 1904-44 & 0.05569 & 0.00228 & 0.53955 & 0.0216 & 0.07029 & 0.00082 & 0.02365 & 0.00 \\
\hline 1904-45 & 0.05189 & 0.00149 & 0.31545 & 0.0087 & 0.0441 & 0.00048 & 0.01396 & 0.000 \\
\hline 1904-46 & 0.05578 & 0.00158 & 0.54762 & 0.01495 & 0.07122 & 0.00075 & 0.02308 & \\
\hline $1904-47$ & 0.05597 & 0.00171 & 0.55961 & 0.01648 & 0.07253 & 0.00082 & 0.02344 & 0.00 \\
\hline $1904-48$ & 0.0556 & 0.00106 & 0.53772 & 0.00964 & 0.07016 & 0.00068 & 0.02199 & 0.00 \\
\hline $1904-49$ & 0.05217 & 0.00187 & 0.3362 & 0.01165 & 0.04675 & 0.00057 & 0.01559 & \\
\hline 1904-50 & 0.05541 & 0.00136 & 0.52597 & 0.01229 & 0.06886 & 0.00073 & 0.02159 & 0.00 \\
\hline 1904-51 & 0.05183 & 0.00316 & 0.31413 & 0.0187 & 0.04396 & 0.00068 & 0.01432 & 0 \\
\hline $1904-52$ & 0.05538 & 0.00149 & 0.52379 & 0.01347 & 0.06861 & 0.00074 & 0.02187 & 0.0 \\
\hline $1904-53$ & 0.0552 & 0.00145 & 0.51148 & 0.01278 & 0.06722 & 0.00073 & 0.02153 & \\
\hline 1904-54 & 0.05545 & 0.001 & 0.52933 & 0.00885 & 0.06925 & 0.00066 & 0.02286 & 0.00 \\
\hline 1904-55 & 0.05576 & 0.00149 & 0.54786 & 0.01401 & 0.07128 & 0.00075 & 0.02291 & 0.0 \\
\hline 1904-56 & 0.05175 & 0.0016 & 0.31247 & 0.0093 & 0.0438 & 0.00049 & 0.01418 & 0.00 \\
\hline 1904-57 & 0.05552 & 0.00148 & 0.53007 & 0.01347 & 0.06926 & 0.00074 & 0.02236 & 0.00 \\
\hline 1904-58 & 0.05603 & 0.00142 & 0.5634 & 0.01359 & 0.07294 & 0.00077 & 0.02307 & 0 \\
\hline 1904-59 & 0.05178 & 0.0016 & 0.31222 & 0.00924 & 0.04374 & 0.0005 & 0.0143 & \\
\hline $1904-60$ & 0.05567 & 0.00166 & 0.53916 & 0.01539 & 0.07026 & 0.0008 & 0.02303 & \\
\hline 1904-61 & 0.05562 & 0.00105 & 0.53887 & 0.00947 & 0.07028 & 0.00068 & 0.02259 & \\
\hline $1904-62$ & 0.05573 & 0.00163 & 0.54435 & 0.01527 & 0.07086 & 0.0008 & 0.02233 & 0.0 \\
\hline $1904-63$ & 0.05554 & 0.00118 & 0.53432 & 0.01071 & 0.06979 & 0.0007 & 0.02309 & 0.0 \\
\hline 1904-64 & 0.05193 & 0.00165 & 0.31973 & 0.00979 & 0.04466 & 0.0005 & 0.01464 & 0.0 \\
\hline $1904-65$ & 0.05582 & 0.00162 & 0.54819 & 0.01528 & 0.07124 & 0.0008 & 0.02401 & 0.00 \\
\hline 1904-66 & 0.1101 & 0.00171 & 4.89548 & 0.06988 & 0.32254 & 0.0031 & 0.0988 & 0.00 \\
\hline $1904-67$ & 0.06006 & 0.00303 & 0.45392 & 0.02234 & 0.05483 & 0.00075 & 0.01899 & \\
\hline $1904-68$ & 0.05168 & 0.00135 & 0.30582 & 0.00765 & 0.04293 & 0.00045 & 0.01442 & 0.0 \\
\hline 1904-69 & 0.05582 & 0.00157 & 0.54927 & 0.01471 & 0.07138 & 0.0008 & 0.0224 & 0.0 \\
\hline 1904-70 & 0.05562 & 0.00152 & 0.53849 & 0.01401 & 0.07023 & 0.00078 & 0.02288 & 0.0 \\
\hline 1904-71 & 0.05221 & 0.00241 & 0.33499 & 0.01504 & 0.04654 & 0.00064 & 0.0142 & 0.0 \\
\hline 1904-72 & 0.05546 & 0.00171 & 0.5413 & 0.01607 & 0.0708 & 0.00079 & 0.02385 & 0.0 \\
\hline 1904-73 & 0.05627 & 0.0012 & 0.57571 & 0.01152 & 0.07421 & 0.00074 & 0.02486 & 0.0 \\
\hline 1904-74 & 0.05208 & 0.00163 & 0.33029 & 0.00995 & 0.04601 & 0.00051 & 0.01447 & 0.0 \\
\hline 1904-75 & 0.05626 & 0.00191 & 0.57541 & 0.01874 & 0.07419 & 0.0009 & 0.02269 & 0.00 \\
\hline
\end{tabular}


Table 5.Major and trace element compositions (ppm) of mafic rocks from the Solonker ophiolite.

\begin{tabular}{|c|c|c|c|c|c|c|c|c|}
\hline Sample & 130928-01 & 130928-02 & 130928-04 & 130814-12 & 130808-09 & 130808-10 & 130808-12 & 130808-13 \\
\hline Rock type & Basalt & Basalt & Basalt & Basalt & Gabbro & Gabbro & Gabbro & Gabbro \\
\hline $\mathrm{SiO}_{2}$ & 49.68 & 50.75 & 51.51 & 53.82 & 47.9 & 47.22 & 45.54 & 47.74 \\
\hline $\mathrm{TiO}_{2}$ & 0.63 & 0.43 & 0.37 & 0.36 & 0.52 & 0.51 & 0.13 & 0.13 \\
\hline $\mathrm{Al}_{2} \mathrm{O}_{3}$ & 19.34 & 15.48 & 14.03 & 15.48 & 15.91 & 16.42 & 18.71 & 13.07 \\
\hline $\mathrm{Fe}_{2} \mathrm{O}_{3}$ & 8.16 & 8.22 & 10.25 & 6.98 & 9.03 & 8.83 & 7.7 & 8.09 \\
\hline $\mathrm{FeO}$ & 3.14 & 4.19 & 7.48 & 3.89 & 6.2 & 5.87 & 5.67 & 6.15 \\
\hline $\mathrm{MnO}$ & 0.12 & 0.12 & 0.18 & 0.13 & 0.16 & 0.15 & 0.16 & 0.15 \\
\hline $\mathrm{MgO}$ & 5.49 & 8.72 & 9.34 & 7.77 & 9.05 & 9.07 & 10.51 & 13.17 \\
\hline $\mathrm{CaO}$ & 9.42 & 10.04 & 8.41 & 8.36 & 13.83 & 14.14 & 12.87 & 13.51 \\
\hline $\mathrm{Na}_{2} \mathrm{O}$ & 4 & 3.67 & 3.29 & 4.3 & 1.15 & 1.18 & 1.22 & 0.77 \\
\hline $\mathrm{K}_{2} \mathrm{O}$ & 0.03 & 0.06 & 0.1 & 0.07 & 0.13 & 0.2 & 0.47 & 0.37 \\
\hline $\mathrm{P}_{2} \mathrm{O}_{5}$ & 0.06 & 0.03 & 0.02 & 0.04 & $<0.01$ & $<0.01$ & $<0.01$ & $<0.01$ \\
\hline LOI & 2.9 & 2.2 & 2.3 & 2.5 & 2.1 & 2 & 2.4 & 2.5 \\
\hline Sum & 99.83 & 99.79 & 99.77 & 99.83 & 99.79 & 99.78 & 99.77 & 99.72 \\
\hline $\mathrm{Mg \#}$ & 0.57 & 0.68 & 0.65 & 0.69 & 0.67 & 0.67 & 0.73 & 0.77 \\
\hline $\mathrm{Sc}$ & 29 & 35 & 40 & 33 & 49 & 42 & 37 & 30 \\
\hline $\mathrm{V}$ & 236 & 217 & 271 & 205 & 238 & 238 & 120 & 200 \\
\hline $\mathrm{Cr}$ & 54.74 & 390 & 136.84 & 280.53 & 41.05 & 198.42 & 157.37 & 1046.84 \\
\hline Co & 24.3 & 35.4 & 45.8 & 32.1 & 40.6 & 38.7 & 45.1 & 46.2 \\
\hline $\mathrm{Ni}$ & 33.5 & 78 & 36.9 & 64.6 & 10.3 & 30.2 & 27 & 70.9 \\
\hline $\mathrm{Cu}$ & 108.5 & 28 & 62.9 & 23.9 & 19.6 & 8.9 & 10.9 & 19.1 \\
\hline $\mathrm{Zn}$ & 57 & 26 & 31 & 11 & 16 & 24 & 57 & 42 \\
\hline $\mathrm{Ga}$ & 16.2 & 11.5 & 10.7 & 9.3 & 12.8 & 13.9 & 10.8 & 10.2 \\
\hline $\mathrm{Rb}$ & 0.6 & 0.8 & 2.3 & 1.2 & 2.7 & 5 & 10.4 & 10.1 \\
\hline $\mathrm{Sr}$ & 241 & 153.7 & 131.4 & 118.8 & 144.1 & 184.5 & 170.1 & 123 \\
\hline $\mathrm{Zr}$ & 46.8 & 28.8 & 10.5 & 26.8 & 4.8 & 11.1 & 3.7 & 6.1 \\
\hline $\mathrm{Nb}$ & 2.2 & 1.5 & 0.9 & 0.5 & $<0.1$ & $<0.1$ & $<0.1$ & $<0.1$ \\
\hline $\mathrm{Ta}$ & $<0.1$ & $<0.1$ & $<0.1$ & $<0.1$ & $<0.1$ & $<0.1$ & $<0.1$ & $<0.1$ \\
\hline $\mathrm{Cs}$ & 0.5 & 0.1 & 0.2 & $<0.1$ & 0.4 & 0.3 & 0.4 & 0.2 \\
\hline $\mathrm{Ba}$ & 35 & 47 & 72 & 53 & 16 & 54 & 42 & 11 \\
\hline $\mathrm{Hf}$ & 1.4 & 0.8 & 0.4 & 0.8 & 0.2 & 0.4 & 0.1 & 0.2 \\
\hline $\mathrm{Pb}$ & 0.5 & 0.2 & 0.6 & 0.5 & 0.6 & 1 & 1 & 0.2 \\
\hline Th & 0.7 & 0.5 & $<0.2$ & 0.5 & $<0.2$ & $<0.2$ & $<0.2$ & $<0.2$ \\
\hline $\mathrm{U}$ & 0.4 & 0.1 & 0.2 & 0.2 & $<0.1$ & $<0.1$ & $<0.1$ & $<0.1$ \\
\hline $\mathrm{La}$ & 4.2 & 2.8 & 1.4 & 2.8 & 0.7 & 1.3 & 0.7 & 0.6 \\
\hline
\end{tabular}




$\begin{array}{ccccccccc}\mathrm{Ce} & 9.4 & 5.6 & 2.3 & 5 & 1.7 & 2.7 & 0.8 & 0.7 \\ \mathrm{Pr} & 1.22 & 0.72 & 0.28 & 0.64 & 0.28 & 0.35 & 0.12 & 0.09 \\ \mathrm{Nd} & 5.3 & 3.3 & 1.3 & 2.8 & 1.6 & 1.9 & 0.6 & 0.4 \\ \mathrm{Sm} & 1.43 & 0.88 & 0.42 & 0.78 & 0.75 & 0.76 & 0.21 & 0.11 \\ \mathrm{Eu} & 0.57 & 0.53 & 0.2 & 0.3 & 0.44 & 0.45 & 0.17 & 0.12 \\ \mathrm{Gd} & 1.89 & 1.43 & 0.82 & 1.12 & 1.28 & 1.12 & 0.43 & 0.33 \\ \mathrm{~Tb} & 0.36 & 0.26 & 0.18 & 0.22 & 0.26 & 0.22 & 0.08 & 0.08 \\ \mathrm{Dy} & 2.22 & 1.66 & 1.37 & 1.53 & 1.67 & 1.35 & 0.52 & 0.7 \\ \mathrm{Ho} & 0.47 & 0.37 & 0.34 & 0.32 & 0.31 & 0.29 & 0.11 & 0.17 \\ \mathrm{Er} & 1.39 & 1.13 & 1.05 & 0.97 & 0.97 & 0.83 & 0.33 & 0.59 \\ \mathrm{Tm} & 0.21 & 0.18 & 0.18 & 0.15 & 0.14 & 0.12 & 0.04 & 0.1 \\ \mathrm{Yb} & 1.32 & 1.17 & 1.2 & 1.04 & 0.88 & 0.73 & 0.26 & 0.76 \\ \mathrm{Lu} & 0.23 & 0.19 & 0.19 & 0.16 & 0.12 & 0.1 & 0.03 & 0.13 \\ \mathrm{Y} & 13.3 & 11.2 & 8.8 & 8.8 & 8.7 & 7.6 & 2.9 & 5.3\end{array}$


Table 6.Major element compositions (wt\%) of siliceous rocks from Solonker ophiolite.

\begin{tabular}{cccccc}
\hline Sample & 130930-11A & 130928-05 & 130929-14 & 130929-15 & $130929-18$ \\
\hline Rock type & $\begin{array}{c}\text { Siliceous } \\
\text { rocks }\end{array}$ & $\begin{array}{c}\text { Siliceous } \\
\text { rocks }\end{array}$ & $\begin{array}{c}\text { Siliceous } \\
\text { rocks }\end{array}$ & $\begin{array}{c}\text { Siliceous } \\
\text { rocks }\end{array}$ & $\begin{array}{c}\text { Siliceous } \\
\text { rocks }\end{array}$ \\
\hline $\mathrm{SiO} 2$ & 85.47 & 70.35 & 79.86 & 71.09 & 88.44 \\
$\mathrm{~A} 2 \mathrm{O} 3$ & 5.97 & 15.68 & 10.81 & 14.1 & 4.03 \\
$\mathrm{TFe} 2 \mathrm{O} 3$ & 4.61 & 5.35 & 2.84 & 6.43 & 4.48 \\
$\mathrm{CaO}$ & 0.26 & 0.16 & 0.1 & 0.17 & 1.07 \\
$\mathrm{MgO}$ & 0.52 & 1.6 & 0.29 & 1.59 & 0.6 \\
$\mathrm{~K} 2 \mathrm{O}$ & 2 & 3.6 & 0.26 & 2.75 & 0.62 \\
$\mathrm{Na} 2 \mathrm{O}$ & 0.01 & 2.21 & 5.46 & 2.84 & 0.02 \\
$\mathrm{MnO}$ & 0.693 & 0.109 & 0.045 & 0.105 & 0.374 \\
$\mathrm{TiO} 2$ & 0.286 & 0.701 & 0.211 & 0.621 & 0.204 \\
$\mathrm{P} 2 \mathrm{O} 5$ & 0.047 & 0.083 & 0.022 & 0.057 & 0.085 \\
$\mathrm{LOI}$ & 0.01 & 0.02 & 0.01 & 0.03 & 0.02 \\
Total & 99.88 & 99.87 & 99.91 & 99.78 & 99.94 \\
\hline
\end{tabular}


Table 7. Hf isotopic data of zircons from the gabbro samples of Solonker ophiolite.

\begin{tabular}{cccccccccc}
\hline $\begin{array}{c}\text { Sample and spot } \\
\text { analysis }\end{array}$ & $176 \mathrm{Hf} / 177 \mathrm{Hf}$ & $1 \sigma$ & $176 \mathrm{Lu} / 177 \mathrm{Hf}$ & $1 \sigma$ & $176 \mathrm{Yb} / 177 \mathrm{Hf}$ & $1 \sigma$ & $\mathrm{Hf}$ & $\mathrm{Lu}$ & $\mathrm{Yb}$ \\
\hline $\begin{array}{c}\text { Gabbro(130808-08) } \\
\text { 130808-08-1 }\end{array}$ & 0.282602 & 0.00001 & 0.002366 & 0.000024 & 0.066748 & 0.000943 & 56163.34174 & 141.5369216926 .1860602 \\
$130808-08-2$ & 0.282672 & 0.000015 & 0.005385 & 0.000042 & 0.134999 & 0.001093 & 85728.00411 & 247.43656091450 .870228 \\
130808-08-3 & 0.282705 & 0.000018 & 0.002127 & 0.000038 & 0.055549 & 0.001222 & 34734.53588 & 94.41035689568 .9135083 \\
Gabbro(SGZ-3) & & & & & & & & & \\
SGZ-3-1 & 0.282906 & 0.000014 & 0.001624 & 0.000049 & 0.035273 & 0.00117 & 25766.29706 & 83.38151444419 .5248361 \\
SGZ-3-2 & 0.282618 & 0.000011 & 0.000861 & 0.000002 & 0.021277 & 0.000052 & 20147.99158 & 54.36439149314 .3722162 \\
SGZ-3-3 & 0.282784 & 0.000011 & 0.000595 & 0.000004 & 0.013687 & 0.000101 & 14611.41248 & 39.58431324212 .6301492 \\
SGZ-3-4 & 0.282467 & 0.000092 & 0.000574 & 0.000009 & 0.014318 & 0.000934 & 7097.651097 & 19.60410329100 .2924206 \\
SGZ-3-5 & 0.282672 & 0.000013 & 0.000655 & 0.000005 & 0.013953 & 0.000184 & 10868.63194 & 31.74802015159 .5837013 \\
\hline
\end{tabular}

Table 7. (Continued)

\begin{tabular}{|c|c|c|c|c|c|c|c|}
\hline Age (Ma) & $\varepsilon H f(0)$ & $1 \sigma$ & $\varepsilon H f(t)$ & $1 \sigma$ & TDM1 & TDM2 & $\mathrm{fLu} / \mathrm{Hf}$ \\
\hline 258.3 & -6.021698119 & 0.623754703 & -0.750919804 & 0.640799506 & 955.0496342 & 1194.813338 & -0.928735096 \\
\hline 258.9 & -3.548286455 & 0.738253501 & 1.218589744 & 0.755911548 & 930.1362498 & 1085.767258 & -0.83780437 \\
\hline 260.4 & -2.368401676 & 0.829730662 & 2.988677475 & 0.846198771 & 798.7354763 & 988.7721231 & -0.93593632 \\
\hline 261 & 4.732774866 & 0.711373171 & 10.19316514 & 0.73040753 & 498.9363867 & 587.3758933 & -0.951072032 \\
\hline 254 & -5.447933737 & 0.642373659 & -0.011752035 & 0.656671506 & 894.3315794 & 1150.509735 & -0.974057547 \\
\hline 257 & 0.43743492 & 0.638830603 & 5.986663082 & 0.65353817 & 655.6721286 & 819.1174346 & -0.9820791 \\
\hline 256 & -10.79489359 & 3.278760679 & -5.270144144 & 3.284928632 & 1097.769153 & 443.518942 & -0.982700828 \\
\hline 255 & -3.535394706 & 0.684995653 & 1.95819776 & 0.698896798 & 813.9460871 & 1041.856794 & -0.980278097 \\
\hline
\end{tabular}

